\title{
França e Brasil: \\ realidades distintas da proteção social, entrelaçadas no fluxo da história*
}

\section{France and Brazil: different social security realities interwoven in the historical flow}

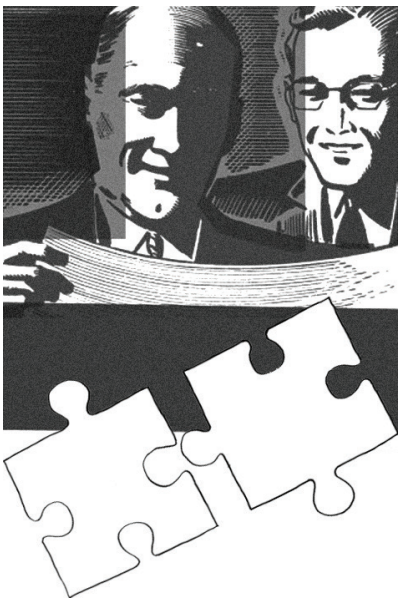

\section{Elaine Rossetti Behring**}

Resumo: Este artigo analisa a destinação de recursos dos orçamentos nacionais do Brasil e da França no ano de 2010, com destaque para a seguridade social, mostrando tendências da alocação do fundo público, o impacto da dinâmica da dívida pública e da financeirização no conjunto das despesas e, sobretudo, as semelhanças e diferenças entre as experiências e condições históricas distintas de um país capitalista periférico e outro central, mas que se entrelaçam na totalidade.

Palavras-chave: Fundo público. Orçamento público. Seguridade social. França. Brasil.

\begin{abstract}
This article analyzes the allocation of resources of 2010's Brazilian and French national budgets, with emphasis on social security, by showing trends in the allocation of public funds, the impact of the dynamics of public debt and the finance of all expenditure. Above all, it analyzes the similarities and differences between the different historical experiences and conditions of a peripheral capitalist country and a central one, which are, however, involved in the whole capitalist logic.
\end{abstract}

Keywords: Public fund. Public budget. Social security. France. Brazil.

* O presente artigo é uma síntese dos principais resultados de nossos estudos quando da realização do pós-doutorado na Universidade de Paris VIII, Cresppa-CSU, a partir da gentil recepção do prof. Yves Sintomer - a quem expresso meu agradecimento - , e com suporte da Capes - Brasil, desenvolvendo projeto intitulado Fundo Público, Orçamento e Seguridade Social: um estudo comparado Brasil — França.

** Doutora em Serviço Social (UFRJ) e professora adjunta da Universidade do Estado do Rio de Janeiro (UERJ), Brasil. É autora de vários trabalhos sobre o tema da política social. Coordenadora do Grupo de Estudos e Pesquisas do Orçamento Público e da Seguridade Social — Gopss - CNPq e bolsista de pós-doutorado da Capes na Universidade de Paris VIII, Cresppa-CSU. E-mail: elan.rosbeh@uol.com.br. 


\section{Introdução}

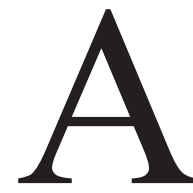

proteção social está, neste momento histórico de crise do capitalismo, no olho do furacão, tanto no espaço geopolítico onde mais se desenvolveu, a Europa, como também no Brasil e demais países da América Latina. No velho continente, a crise se manifesta hoje ${ }^{1}$ de forma contundente por meio da dívida dos Estados, que evoluiu de maneira explosiva após as operações de salvamento das instituições financeiras entre 2007 e $2009 .{ }^{2}$ A resposta a esse crescimento da dívida, ilegítima e odiosa, dependendo da história dos países (Chesnais, 2011), vem sendo programas de austeridade, o que inclui cortes ou redimensionamentos dos gastos públicos, com destaque para os sociais, processo que unifica o novo e o velho continente. Mas inclui também, e destacadamente, processos de mercantilização e privatização nesse campo, sendo estes últimos uma espécie de marca do período.

Este é um momento em que estão exponenciadas as expressões da questão social, com destaque para o desemprego endêmico que assola a Europa, ${ }^{3}$ acompanhado da precarização e superexploração do trabalho. Nessa região, a era do pleno emprego combinado à política social abrangente, e de um capitalismo supostamente controlado e organizado, parece uma espécie de miragem, de sonho cada vez mais distante. A tendência da política social tem sido deslocar-se para políticas de combate à pobreza, esta última em visível crescimento. A transferência de renda submetida a tetos, critérios de renda e contrapartidas "ativas" tornou-se um carro-chefe, em detrimento do emprego e da universalização do acesso a serviços gratuitos, embora essa direção

1. Já tivemos a oportunidade de discutir o ciclo longo de estagnação do capitalismo que se arrasta desde o início dos anos 1970, adotando a análise de Ernest Mandel. Portanto, a crise não é recente, mas coloca-se como tendência de larga duração, de período. Contudo, inúmeras análises mostram a sua intensificação brutal a partir de 2007, tendo como polo dinâmico os países do centro do capitalismo, especialmente os Estados Unidos, e o capital financeiro. Conferir Mandel, 1982 e nossas análises em Behring, 1998, 2008a e 2010.

2. A relação dívida pública bruta-PIB nos países da zona euro (dezessete países) evoluiu de $69,2 \% \mathrm{em}$ 2000 para $87,2 \%$, em 2011. O momento explosivo após um período de oscilações foi exatamente a passagem de 2007 (70,2\%) para 2008 (80\%), a partir do qual essa relação não parou de crescer globalmente e em alguns países de forma destacada, a exemplo da Grécia, cuja relação dívida-PIB passou de 103,4 para 165,3\%. Disponível em: <http://epp.eurostat.ec.europa.eu>. Acesso em: 28 maio 2012.

3. Em março de 2012, a taxa de desemprego na zona euro (dezessete países) encontra-se na média de $10,9 \%$ da população economicamente ativa, segundo a definição da OIT, mas em alguns países ultrapassa a marca dos 20\%, a exemplo da Espanha (23,8\%) e da Grécia (21,4\%). Disponível em: <http://epp.eurostat. ec.europa.eu>. Acesso em: 28 maio 2012. 
seja disputada em cada espaço nacional e mediada pela história de cada país. Assim, produziram-se múltiplas realidades e cenários da proteção social, ou seja, há um efeito de heterogeneização da proteção social, numa direção geral de menos proteção social universal, em vez do sentido social-democrata clássico dos anos de crescimento. O anunciado fim do Estado Social não ocorreu como previsto, mas certo nível de desmonte foi inevitável no contexto da ofensiva neoliberal. ${ }^{4}$

Por outro ângulo, se o Estado Social europeu dos anos do pós-guerra tinha seu fundamento no pleno emprego (em sentido keynesiano), também o tinha nas lutas dos trabalhadores, já que os direitos sociais têm uma natureza contraditória e resultam das pressões e contrapressões da luta de classes e seus segmentos (Behring e Boschetti, 2006). Anos de neoliberalismo fragilizaram as organizações políticas dos trabalhadores, derruindo a resistência à perda de direitos nos vários países, ainda que de forma diferenciada. As deslocalizações (Chesnais, 1996) e a reestruturação produtiva produziram fortes impactos na consciência e organização política em todos os espaços nacionais (Antunes, 2009). O que dizer do crescimento da direita mais reacionária na Áustria e na França ${ }^{5} \mathrm{~A}$ fragilidade da força política do campo do trabalho implica a vulnerabilidade dos direitos e das políticas sociais, produzindo processos de expropriação contundentes (Fontes, 2010), ${ }^{6}$ inclusive com a mercantilização clara dos serviços de saúde e educação, além do crescimento da previdência privada aberta e fechada em articulação com as instituições financeiras. Os tempos contrarreformistas ${ }^{7}$ (Behring, 2003) insistem em perdurar e até se apro-

4. Estudo de Boschetti (2012) sobre as contrarreformas na Europa mostra claramente as tendências em curso com mudanças regressivas na esfera previdenciária e da saúde, e o crescimento das prestações sociais submetidas a critérios de renda, diga-se, assistenciais, no sentido brasileiro.

5. Nas eleições presidenciais francesas, apesar da débâcle de Nicolas Sarkozy bastante comemorada nas ruas e do crescimento e vitória no segundo turno da candidatura de François Hollande, do Partido Socialista, foi preocupante a inserção nas hostes populares da candidatura de Marine Le Pen, que representa uma direita reacionária e com forte conotação fascista no espectro político francês. Houve reflexo desse crescimento nas legislativas com o retorno da Front Nacional ao Parlamento após 24 anos de ausência, mas registrando que o PS conquistou maioria absoluta, o que oferece à Hollande uma forte base parlamentar de sustentação.

6. Vale a pena conferir a rica e interessante polêmica entre Fontes (2010) e Harvey (2004) em torno da caracterização deste último de que estaríamos num processo de acumulação por espoliação. A discussão envolve a atualidade do conceito de acumulação primitiva do capital. Ambos estão focados em compreender a dinâmica contemporânea da acumulação num diálogo com Marx, mas, por caminhos analíticos diferentes, esclarecem os processos que atingem duramente as condições de vida e trabalho das maiorias, incluindo as perdas no campo dos direitos sociais.

7. Outros autores da literatura francesa utilizam essa caracterização: Chesnais, 2011, Duval, 2008 e Bensaid, 2009; Dourille-Feer et al. (2011). 
fundar no contexto da crise do capital - que ademais vai muito além de uma "crise da finança" ou de uma "desordem financeira" como querem fazer crer alguns analistas e periodistas. ${ }^{8}$

O momento que mais requisita um choque de civilização e rupturas profundas com a lógica mercantil é exatamente aquele onde são aplicados choques de barbárie. Exemplo disso são os planos de ajuste grego, ${ }^{9}$ espanhol e irlandês, impostos pela troika, ${ }^{10}$ diga-se, União Europeia (EU), Banco Central Europeu (BCE) e Fundo Monetário Internacional (FMI), em nome do equilíbrio das contas públicas, mas para efetivamente assegurar o fluxo de recursos para o capital financeiro. Sabemos que essas medidas implicam continuar realizando uma dramática punção do fundo público (Behring, 2010) para especuladores e proprietários, além de quadros intermediários que se beneficiam dessa conjuntura para seus luxos pessoais (Lordon, 2008). ${ }^{11}$

8. A revista brasileira Carta Capital publicou recentemente um dossiê sobre a "desordem financeira mundial" (27/5/2012). Pela via acadêmico-profissional, muitos são os trabalhos que caracterizam o momento como crise da finança. Destacamos o trabalho de Frédéric Lordon, que tem o sugestivo título Jusqu'à quand? Pour en finir avec les crises financières (Raisons D’Agir, 2008. Tradução: Até quando? Para acabar com as crises financeiras). Trata-se de uma imprescindível pesquisa e análise crítica sobre o universo da finança, sua dinâmica interna competitiva e destrutiva, sua novilíngua e seu ethos. Apesar das precauções do autor ao admitir que a lógica atual da finança seja um sintoma por excelência de uma crise estrutural (2008, p. 202), ele não foge a duas tentações: de prescrever medidas de regulação para acabar com as crises financeiras; e de autonomizar a finança da, equivocadamente, chamada economia real, o que limita sua análise. No entanto, as medidas sugeridas são importantes numa perspectiva de transição para outra sociabilidade, considerando os impactos que poderiam ter sobre a dinâmica contemporânea do capitalismo. Lordon é um dos signatários do Manifeste D’Economistes Atterrés, articulação de mais de 600 economistas franceses que identifica dez falsas evidências no discurso econômico corrente e propõe um programa de ruptura com essa lógica, a partir de 22 orientações de medidas. É, a nosso ver, uma perspectiva que vai muito além da social-democracia, ainda que não assuma claramente uma perspectiva anticapitalista. Uma visita detida ao Manifeste revela, na verdade, um conjunto muito interessante de medidas de transição.

9. A respeito dos impactos da crise e do plano de austeridade na Grécia, consultar o excelente documentário Debtocracy (direção de Aris Hatzistefanou e Katerina Kitidi, 2011). Um debate sobre a questão da dívida odiosa e sobre a estratégia das auditorias das dívidas também é central nesta película.

10. Sobre a troika, os mesmos diretores citados na nota anterior realizaram o imprescindível documentário Catastroika (2012), que mostra a pilhagem neoliberal ao redor do mundo, por meio das privatizações, até chegar à Grécia de hoje, com impressionante riqueza de detalhes e dados.

11. O cinema, mais uma vez, produz uma forte metáfora da barbárie: Cosmopolis, de David Cronenberg (2012), é um impactante relato sobre o ethos do capitalismo contemporâneo e os obscuros lugares objetivos e subjetivos a que pode levar a dinâmica do tempo presente, a partir do frio olhar de um especulador que praticamente vive e realiza suas operações em uma limusine nas ruas de Nova York. 
Enquanto isso, o Brasil aparece ao mundo como um "eldorado", ${ }^{12}$ terra do novo desenvolvimentismo, onde parte da população pobre migrou para a classe média, ${ }^{13}$ resultado de políticas públicas consistentes, e de uma política econômica bem conduzida e pouco vulnerável aos fortes abalos externos, como sustentam o governo, agências internacionais e alguns intelectuais. Cabe problematizar esse novo mito brasileiro, ${ }^{14} \mathrm{e}$ o quanto de verdade e de mera propaganda existe em sua difusão. E o caminho de mostrar o que é efetivamente investido em políticas sociais pelo Estado, bem como a lógica persistente que preside a construção do orçamento público no Brasil há alguns anos, é bastante profícuo. Afinal, a tarefa da ciência, especialmente do pensamento social crítico, é a de ir além das aparências, desconfiar das opiniões formadas e desconcertá-las, desnudar a aparente irracionalidade de determinados processos, desmistificar os fetichismos que perduram e se renovam.

Nosso percurso inicia comentando alguns traços gerais dos dois países, construindo um patamar de observação sobre a dinâmica da alocação do fundo público no ano de 2010, escolhido como marco da pesquisa por ser o último ano com dados completos disponíveis da prestação de contas dos dois Estados nacionais. Em seguida realizamos uma incursão sobre a dinâmica do orçamento público e do financiamento das políticas públicas nos dois países, em comparação com a carga da dívida pública, para na sequência compreender a construção do padrão de proteção social e da seguridade social, e seu financiamento nos dois países. Veremos que a evolução recente expressa tendências gerais para a política social no capitalismo central e periférico, mediadas por suas particularidades. O debate sobre o Brasil $1^{15}$

12. Consultar, por exemplo, publicação sobre o Brasil, intitulada Brésil - Um géant accessible, da Chambre de Commerce et d'Industrie de Paris destinada aos investidores franceses, onde este termo aparece mais de uma vez, apesar das recomendações de prudência (CCIP, 2010).

13. Segundo o jornal Folha de S.Paulo (29 maio 2012), a Secretaria de Assuntos Estratégicos da Presidência da República definiu: "as pessoas com renda familiar per capita entre cerca de R\$291 e R\$ 1.019 são as que formam a classe média brasileira", o que representa $54 \%$ da população. Os dados estão disponíveis em: <http://sae.gov.br/novaclassemedia/numeros/>. A publicação francesa citada na nota 14 também faz referência a esse mesmo termo. Considerando o poder de compra desse corte de renda e os serviços públicos disponíveis no Brasil, bem como a elevadíssima concentração de renda e riqueza, é no mínimo surpreendente e, no limite, constrangedora essa caracterização oficial amplamente difundida no mundo dos negócios, com o olhar voltado para a capacidade de consumo.

14. Não é o primeiro nem o único. Conferir o belo livro de Marilena Chaui, 2000, lançado por ocasião dos 500 anos do descobrimento, e que utiliza a categoria de mito fundador para explicar dinâmicas recorrentes na história brasileira.

15. A partir dos estudos que vimos desenvolvendo desde 2003 no Grupo de Estudos e Pesquisas do Orçamento Público e da Seguridade Social (Gopss), FSS-UERJ, CNPq. 
será pontuado ao longo do texto, buscando elementos comparativos. Essa opção de perscrutar a proteção social francesa e pontuar correlações com a brasileira deve-se ao nosso próprio movimento intelectual, que buscou apreender a dinâmica francesa de forma mais sistemática, considerando o conhecimento mais bem consolidado que dispomos sobre a proteção social brasileira e seu financiamento. Ao longo do texto vamos estabelecer inferências e relações entre essas duas experiências históricas tão diferentes, mas que se articulam na dinâmica complexa do capitalismo contemporâneo, a partir de seus lugares diferenciados na hierarquia dos países na economia política mundial.

No entanto, cabe aqui uma advertência. Para estabelecer aproximações comparativas, é necessário delimitar o campo efetivamente comparável. O estudo de Elbaum (2011) chama a atenção para a prudência que as comparações internacionais requisitam, pois sob os números podem não estar os mesmos conceitos e critérios - e em geral não estão. Portanto, faz-se necessário harmonizar os conceitos para delimitar o campo mais comum possível, a partir do qual será desdobrada a análise. A referida autora está discutindo a comparação entre países da União Europeia, mas entendemos que o cuidado deve ser redobrado quando estão em foco experiências históricas tão díspares quanto a francesa e a brasileira. E aqui encontramos problemas reais no nosso caminho de pesquisa, pois a complexidade do sistema francês de proteção social faz o pesadelo dos pesquisadores estrangeiros (Barbier e Théret, 2009 , p. 16), tornando árduos os estudos comparados e colocando em questão os "modelos" que vêm orientando boa parte desses estudos. ${ }^{16}$ Há diferenças significativas entre o padrão de proteção social francês e brasileiro, especialmente no quesito financiamento, mas não só. Estas dificultam sobremaneira a comparação de seus traços gerais quanto à concepção, cobertura efetiva, relação entre direitos e políticas, e estrutura institucional; bem como quanto às incidências das orientações neoliberais para a política social no período e impactos da crise. No entanto, em que pesem essas dificuldades, o estudo comparativo permite identificar tendências

16. Em geral as grandes referências são os parâmetros de Titmuss (1974) e de Esping-Andersen (1991). De nossa parte, já fizemos referência à importância de buscar nas relações entre as classes, na estrutura produtiva, na configuração do Estado, na cultura política, enfim, na história das formações nacionais, as raízes das trajetórias da política social em cada país, sem abrir mão da sua relação com a totalidade da vida social, política e econômica que marca os vários períodos históricos. A inserção das experiências particulares na totalidade é o que permite inferências comparativas (Cf. Behring, 1998 e Behring e Boschetti, 2006). A intrincada lógica francesa confirma que esse é um caminho mais fecundo que o dos tipos ideais, ainda que permaneça na literatura a justificação e defesa de sua utilidade (Elbaum, 2011, p. 49-60). 
gerais, estabelecer correlações, apanhar mediações que se produzem na totalidade concreta, e identificar novos elementos a partir de um patamar de observação reposicionado.

O presente trabalho resulta de uma pesquisa sobre o eixo do financiamento, mas para avançarmos fez-se necessário mapear o desenho específico da proteção social à francesa (Barbier e Théret, 2009, p. 7), buscando eventualmente traçar linhas de encontro e desencontro entre esta e o que temos no Brasil. Veremos que determinadas lógicas percorrem a experiência francesa contemporânea e a brasileira, já que esses países construíram experiências híbridas de proteção social, desdobradas daqueles dois momentos originários (bismarckiano e beveridgeano), o que também os aproxima, à despeito das diferenças.

\section{França e Brasil: parâmetros constitutivos da análise}

Estamos aqui tratando de países que ocupam lugares diferenciados na economia e na geopolítica mundial: a França entre os países do centro do capitalismo, segunda economia da Zona Euro e membro do G7; e o Brasil: na periferia imediata do mundo do capital, integrando o grupo dos mercados emergentes, os chamados Brics $^{17}$ (Brasil, Rússia, Índia, China e África do Sul), membro do G20, considerado como a sexta economia do mundo, com um PIB pujante, porém combinado à alta concentração da riqueza e à desigualdade perene. Alguns elementos são ilustrativos do lugar diferenciado e da relação desigual entre esses dois países que possuem um partenariat stratégique (parceria estratégica) e liens irréversibles (ligações irreversíveis), do ponto de vista econômico. Enquanto existem cerca de 450 empresas francesas em ação direta no Brasil e esse país é o quarto ou quinto fornecedor de mercadorias, em geral bens manufaturados, o Brasil é o 15. fornecedor da França, em geral de matérias-primas, e possui poucas empresas atuando em solo francês (Entrevista do embaixador Philippe Lecourtier, In: CCIP, 2010).

A França tinha, em 2010, uma população de 64,7 milhões de habitantes, com um PIB per capita em torno de $€ 29.900,00$ (Eurostat, 5/6/2012). O Brasil contava no mesmo ano, com 190,7 milhões de habitantes e um PIB per capita de

17. Termo criado em 2001 pelo Banco Goldman Sachs e que se tornou corrente no mainstream econômico (cf. Rol, 2010, p. 112, In: CCIP, 2010). 
R\$ 19.073,26 (IBGE, 3/3/2011), ou seja, para efeito de comparação, o PIB per capita brasileiro em euros pode ser calculado em $€ 8.562,06 .{ }^{18}$ Sabemos que os cálculos per capita são sempre limitados, já que quase nada revelam sobre o efetivo acesso à riqueza socialmente produzida e à propriedade, considerando as classes e seus segmentos. De outro ângulo, na situação em foco, abordamos poderes de compra diferentes das duas moedas. ${ }^{19}$ Contudo, esse dado torna evidente que, com um PIB menor, um território de dimensões continentais e longas fronteiras, e uma população quase três vezes maior e com mais necessidades historicamente insatisfeitas, o Brasil, apesar das aspirações de potência econômica hoje mais próximas de sua realização, está longe de condições de vida e trabalho dignas para a maioria de seus habitantes.

A França conviveu com o pleno emprego fordista-keynesiano (Harvey, 1993) do pós-guerra e desenvolveu um Estado Social com ampla cobertura e direitos, mesmo considerando a natureza híbrida de seu padrão de proteção social, que iremos comentar adiante. No contexto da hegemonia neoliberal e da onda longa de estagnação aberta nos anos 1970, houve perdas de direitos, crescimento do desemprego e aumento contundente da pobreza. Nos últimos anos, no ápice da crise, a taxa de desemprego oscilou entre 9\% e 10\% da PEA (em junho de 2012, segundo dados do Eurostat), chegando em 9,4\% da PEA (esta última, em torno de 28,1 milhões de pessoas entre 15 e 64 anos em 2010), ${ }^{20}$ o que corresponde a cerca de 2,6 milhões de desempregados, ${ }^{21}$ dado que seria impensável nos chamados anos de ouro. Em 1975, a taxa de desemprego na França era de 3,5\% da PEA. ${ }^{22}$ Quanto à pobreza, cuja relação com a condição do trabalho é decisiva, tem-se que as pessoas

18. Data da cotação utilizada: 31/12/2010. Taxa: 2,228 reais, Brasil (790) = 1 Euro (978), Banco Central do Brasil. Acesso em: 5 jun. 2012.

19. Vamos utilizar no texto a comparação simples com base na taxa de câmbio no último dia do ano em foco, 2010. A OCDE vem desenvolvendo um indicador para análises internacionais comparadas, o PPA Parité de Pouvoir d'Achat (Schcreyer e Koechlin, 2002), que não será utilizado neste trabalho, considerando a complexidade de seu cálculo e aplicação. O Eurostat também fornece dados sobre índices de preços com base nesse indicador em sua base estatística. Não encontramos estudos sobre o Brasil em comparação com outros países com base nesse índice.

20. Disponível em: <http://www.insee.fr/fr/themes/tableau.asp?reg_id=0\&ref_id=NATCCF03170>. Acesso em: 7 jun. 2012.

21. Disponível em: < http://www.insee.fr/fr/themes/tableau.asp?reg_id=0\&ref_id=NATASF03362>. Acesso em: 7 jun. 2012.

22. Disponível em: <http://www.insee.fr/fr/themes/tableau.asp?reg_id=0\&ref_id=NATnon03337>. Acesso em: 7 jun. 2012. 
que possuíam um rendimento abaixo de $60 \%$ da média nacional (parâmetro: $€$ 876,00), em 2009 representavam 18,4\% da população e em 2010, 19,3\% (Eurostat, 14/6/2012), o que revela uma tendência ascendente e visível, sobretudo no espaço urbano francês.

O Brasil não conheceu a situação de pleno emprego fordista-keynesiano, aproximando-se, na melhor das hipóteses, do que alguns economistas regulacionistas caracterizaram como fordismo periférico (Lipietz, 1988, e Saboia, 1988). Este termo-síntese procura mostrar que a apropriação dos ganhos de produtividade nos acordos coletivos de trabalho foi sempre parcial ou mesmo residual no Brasil, em virtude de uma correlação de forças bastante desfavorável ao trabalho, especialmente no auge desta experiência, o regime militar pós-1964. Acrescente-se que o acesso aos serviços sociais e direitos foi sempre limitado, por longo tempo segmentado, deixando largas parcelas da população sem qualquer proteção mesmo após a Constituição de 1988, que institui a seguridade social no país (cf. Boschetti, 2003; Boschetti e Salvador, 2006; e Lopes, 2011). Na verdade, existe uma forte informalidade no mundo do trabalho e grande precariedade do emprego, com repercussões duradouras na proteção social brasileira, seja do ponto de vista da arrecadação, seja da cobertura, considerando a intrínseca relação entre trabalho e proteção social, tanto do lado da despesa, quanto da receita, para a política social (Boschetti, 2003 e 2006; Mota, 1995). Por outro lado, os indicadores brasileiros sobre a questão do emprego são polêmicos. O IBGE, instituto público oficial que produz o Censo e a maior parte dos dados estatísticos do país, indicava, em novembro de 2010, uma taxa de desocupação de 5,7\%, referente a um universo de seis regiões metropolitanas do país, e não ao conjunto da população economicamente ativa. Envolve, portanto, cerca de 1,5 milhão de desocupados (mas em busca de ocupação) e 22,3 milhões de pessoas ocupadas, das quais cerca de 10,3 milhões possuem carteira assinada, o que significa emprego com direitos, ainda que dentro das condições de proteção do país. Isto significa que aproximadamente $50 \%$ da força de trabalho ocupada se encontra em condições precárias, na informalidade e sem direitos adquiridos de proteção social. O Dieese, órgão de assessoria e estudos ligado ao movimento sindical, por sua vez, considera sete principais regiões metropolitanas e opera com um conceito mais amplo de desocupação, o que leva a números diferentes e, a nosso ver, mais próximos da realidade. Segundo essa instituição, existia $11,9 \%$ de desemprego aberto em relação à PEA em sete regiões metropolitanas, num contexto de tendência de queda do desemprego, se comparado com outros anos. Não existe um cálculo global unificado da taxa de desemprego no país, pos- 
sivelmente em virtude das dificuldades geradas pela alta ocupação na informalidade e na precariedade. Mas o Dieese ${ }^{23}$ revela uma PEA de 107 milhões de pessoas entre dez e 65 anos. Ao subtrair dessa conta 1,7 milhão de crianças e adolescentes entre dez e catorze anos, que não deveriam ser consideradas como em condições de trabalhar, ${ }^{24}$ teremos uma PEA de 105,3 milhões de pessoas, o que mostra a fragilidade dos nossos indicadores de desemprego nos cálculos das duas instituições, os quais abrangem cerca de um quinto da PEA, ainda que esta seja uma amostra significativa, de regiões metropolitanas importantes, e que revele tendências.

No que se refere à pobreza no Brasil, diretamente relacionada à condição do trabalho, o IBGE (novembro de 2011) ${ }^{25}$ esclarece os critérios para sua apuração: o Programa Bolsa Família, de transferência de renda, considera extremamente pobres famílias com renda domiciliar per capita de até $\mathrm{R} \$ 70$, e pobres, aquelas com até R\$ 140. O Benefício de Prestação Continuada da Assistência Social (BPC-Loas), programa constitucional de transferência de renda que dá direito a um salário mínimo para idosos e pessoas com deficiência, estabelece como critério de acesso um rendimento domiciliar per capita inferior a um quarto de salário mínimo, também de pobreza extrema. O Plano Brasil Sem Miséria, recentemente lançado pelo governo Dilma Roussef, combina a linha de $\mathrm{R} \$ 70$ de rendimento domiciliar per capita com outras dimensões, como falta de saneamento básico. O IBGE informa ainda que: "o valor de meio salário mínimo per capita, por sua vez, é o valor referencial no Cadastro Único para Programas Sociais do governo federal, que considera a pobreza absoluta. Já os países europeus, em geral, publicam indicadores de pobreza monetária a partir do valor de $60 \%$ da renda mediana nacional". Evidentemente, nossos critérios levam à constatação do pauperismo extremo e absoluto, orientando políticas fortemente focalizadas e seletivas, o que institui uma diferença conceitual central a ser considerada em qualquer análise dos dois universos aqui pesquisados, a França e o Brasil. O salário mínimo legal é um parâmetro para aferir a pobreza, bem como para destinar prestações sociais nos dois países. Vejamos seu valor em 2010: na França, $€ 1.343,77$ (Eurostat, 18/6/2012); no Brasil, R \$ 510,00,

23. Disponível em: $<$ http://www.dieese.org.br/anu/AnuTrab2010/Arquivos/indicadores_mercadotrabalho_estruturamerctrabalho_t47.html>. Acesso em: 30 jun. 2012.

24. O que consideramos injustificável nas estatísticas oficiais brasileiras, especialmente após a entrada em vigor, em 1990, do Estatuto da Criança e do Adolescente.

25. Documento do IBGE (Brasil) intitulado "Indicadores Sociais Municipais 2010: incidência de pobreza é maior nos municípios de porte médio", nov. 2011. Disponível em: <http://www.ibge.gov.br/home/ presidencia/noticias/noticia_visualiza.php?id_noticia=2019\&id_pagina=1>. Acesso em: 14 jun. 2012. 
o que corresponde a $€ 228,90 .{ }^{26}$ Temos então que o salário mínimo na França é 5,87 vezes maior que o brasileiro. Esta é uma diferença marcante, mesmo considerando que o salário mínimo brasileiro recuperou parcialmente seu poder de compra nos últimos anos com aumentos acima da inflação, base inclusive da melhoria suave dos indicadores sociais brasileiros no último período. Este impacto nos indicadores sociais (ex. coeficiente de Gini) deu-se inclusive porque o salário mínimo é indexador das aposentadorias, pensões e do BPC, o que evidentemente não justifica, a nosso ver, a existência de uma nova classe média brasileira. ${ }^{27}$ Por outro lado, poder-se-ia argumentar um custo de vida menor no Brasil. Sobre isso, cabe ponderar que a oferta de serviços públicos na França, a exemplo da água e dos suportes à moradia e transporte, educação e lazer, bem como as alocações familiares para infância e dependência, torna muito frágil o argumento. O peso desses itens no consumo diário dos trabalhadores brasileiros é efetivamente muito maior.

Para adensar nossa reflexão acerca das diferenças entrelaçadas, cabe considerar alguns traços do processo histórico da formação social dos dois países. A França realizou uma revolução burguesa clássica (Moore Jr., 1983), com um conjunto de implicações econômicas, políticas e culturais de longa duração daí decorrentes. Existe no país um impregnado sentido republicano de nação, de cidadania e autonomia, e uma relação com o mundo do trabalho marcada pelo contrato social (no mais profundo sentido rousseauniano), e por direitos adquiridos e assegurados pelo Estado, mesmo com as reconhecidas perdas recentes. É um país que realizou uma reforma agrária ampla, é estruturado sobre a pequena e média propriedade rural, em articulação com uma forte indústria de ponta de manufaturados. Por outro lado, a intensa experiência histórica das lutas de classe - a Revolução de 1789 e seus desdobramentos, as lutas de 1848, a Comuna de Paris em 1871, o Maio de 1968, a greve geral de 1995, entre outras - marca profundamente a vida política e as lutas sociais, com intensos debates nacionais. Há grandes manifestações de rua, à esquerda e à direita, numa sociedade onde esses termos guardam sentido, mesmo com todos os esforços empreendidos para diluir essas fronteiras, no contexto do neoliberalismo e da restauração capitalista no Leste europeu. Mas há também grandes e violentos paradoxos na terra de nascimento da Declaração dos Direitos do Homem,

26. Data da cotação utilizada: 31/12/2010. Taxa: 2,228 reais, Brasil (790) $=1$ euro (978).

27. É impressionante como essa construção ideológica da "nova classe média brasileira" se tornou uma espécie de verdade corrente, em especial na caracterização do mundo dos negócios, que veem estes segmentos pouco acima das linhas draconianas de pobreza como novos consumidores. Cf. Rol (In: CCIP, 2010, p. 121). 
a exemplo do governo colaboracionista de Vichy, durante a ocupação nazista na França, ou da relação com os argelinos durante a guerra de independência desse país, entre 1956 e 1962, entre outros. Assim, não se pode nem romantizar a França nem subestimar o potencial de mudança que a luta de classes desencadeia no país, toda vez que vem à tona com suas barricadas. ${ }^{28}$ Essas características, várias análises indicam (Duval, 2008; Barbier e Théret, 2009), tiveram no último período um papel importante em certa contenção da ofensiva neoliberal sobre os direitos sociais e as políticas que lhes dão materialidade, ainda que tenham ocorrido perdas.

O Brasil, por sua vez, chegou à modernidade por uma via não clássica, uma espécie de revolução burguesa sem revolução e pelo alto, repleta de processos de modernização conservadora pelo menos até a autocracia burguesa de 1964-84 (Fernandes, 1987). Suas marcas de longa duração são: o peso do escravismo, especialmente sobre a relação com a força de trabalho, localizada entre a tutela e a força; a heteronomia e a dependência, que expressam um sentido de inserção na economia-mundo voltado para fora e não para um mercado interno de massas, este último sempre contido, diante de suas potencialidades; uma cultura política antidemocrática, antipública e patrimonialista na relação com o Estado, profundamente enraizada na burguesia brasileira, com desdobramentos para o conjunto da sociedade (Prado Jr., 1942 e 2011; Fernandes, 1987; e Behring, 2003). Esses processos deixaram fulcros importantes no mundo do trabalho, onde o conformismo e a cooptação tomaram e tomam muitas vezes o lugar da resistência, ainda que esta última exista. São marcas que fragilizam a luta pelos direitos e para além deles. Tais características propiciaram obstáculos aos avanços democráticos preconizados pela Constituição de 1988, que foram atropelados pela contrarreforma neoliberal avassaladora a partir de 1995, como tivemos a oportunidade de demonstrar (Behring, 2003), dentre os quais a constituição de um padrão de proteção social efetivamente abrangente.

Esses traços gerais, e que já geraram tratados inteiros e clássicos sobre os dois países, são aqui apenas pontuados, com o objetivo de constituir nosso patamar de observação para a análise da lógica da alocação do fundo público, ${ }^{29}$ realizada por

28. Tive a oportunidade de traçar algumas linhas sobre meu recente aprendizado acerca dos paradoxos franceses em: "Outubro. 1961. O silêncio sobre a repressão à resistência argelina em Paris", publicado no blog Mídia e Questão Social, em 7/4/2012, a convite de Mione Hugon. Disponível em: <http://midiaequestaosocial.blogspot.com.br/2012/04/editoria-volta-do-mundo-mundo-da-volta.html>.

29. Sobre o fundo público, vimos adensando esta categoria a partir de uma compreensão de seu lugar estrutural no circuito do valor, tendo como referência a crítica marxista da economia política. Conferir Behring, 2008a, 2010 e 2012a [no prelo]. 
meio do orçamento público nos dois países, que não pode ser vista sem a dinâmica da política e da cultura. Afinal, sob os números do orçamento público encontram-se disputas tensas e intensas entre as classes e seus segmentos.

\section{A lógica da alocação do fundo público: orçamento no Brasil e na França}

Estabelecidos os parâmetros, trata-se agora de perscrutar semelhanças e diferenças na organização do orçamento público, o qual revela o sentido da alocação do fundo público nos dois países, buscando identificar os pesos percentuais das despesas públicas em alguns itens centrais, bem como algumas características das receitas. Nosso objetivo é o de identificar tendências da composição e da alocação de recursos, na perspectiva de observar onde essas experiências se entrelaçam e se afastam.

No Estado nacional francês, desde 2006, entrou em vigor a Lolf (Loi Organique Relative aux Lois de Finances), que rege a construção do orçamento e a prestação de contas, reformando uma lei de 1959 que até então orientava esse processo. Segundo a LOLF, o orçamento é construído a partir de missions (missões), o maior nível de agregação de despesas, seguido de programmes (programas) e actions (ações), níveis de agregação menores, em escala decrescente. Essa organização geral corresponde às funções no orçamento brasileiro, às quais se seguem as subfunções e programas, que, por sua vez, se desdobram em projetos, atividades e ações. Existem na França 32 missões, 123 programas e em torno de 500 ações (Didier, 2011, p. 9; Baslé, 2004, p. 26-7). Já no Brasil, temos 28 funções, 43 subfunções, e após esse nível de desagregação, os diversos programas seguidos de atividades, projetos e ações (MTO, 2010, p. 108-111). Para efeito de comparação geral da lógica de alocação do fundo público nos dois países, vamos estabelecer correlações entre os níveis maiores de agregação dos recursos, ou seja, missões e funções, podendo recorrer eventualmente aos níveis imediatamente subsequentes para esclarecer dinâmicas determinadas ou aproximar agregados entre os dois países.

Diferente do Brasil, onde existem três orçamentos que compõem o Orçamento Geral da União (OGU) desde a Constituição Federal de 1988 - Orçamento Fiscal, Orçamento da Seguridade Social e Orçamento das Estatais -, a França adota um orçamento do Estado Nacional, de natureza fiscal. A Sécurité Sociale, cuja complexidade será abordada no item subsequente deste texto, possui um or- 
çamento separado e regulado pela LOLFSS (Loi Organique Relative aux Lois de Financement de La Securité Sociale), que orienta as LFSS (Lois de Financement de La Securité Sociale), leis anuais também aprovadas na Assembleia Nacional (Parlamento francês), mas cujo trâmite é diferente da Loi des Finances. No Brasil, criou-se, na Constituição de 1988, um Orçamento da Seguridade Social em separado, sob gestão do Estado, mas que sofre fortemente as injunções das disponibilidades de caixa, o que significa estar em separado ma non troppo (mas não muito!), apesar dos desejos constituintes. Explicamo-nos: as incidências dos ajustes fiscais brasileiros, a exemplo da persistência da Desvinculação de Receitas da União (DRU) e do superávit primário, atingem profundamente os recursos da Seguridade Social brasileira. ${ }^{30}$ Isto não ocorre com a Sécurité Sociale francesa, em que esses mecanismos de punção exclusivamente fiscal de recursos não existem, pelo contrário, há inversão crescente de recursos fiscais para a mesma. Essa dinâmica tem relação com a concepção da Sécurité Sociale na França, como veremos adiante. Mas, quanto ao Brasil, tal lógica guarda raízes profundas no seu lugar subordinado na economia-mundo, sua vulnerabilidade externa e, do ponto de vista político, suas dificuldades - que tem origem na dinâmica das classes sociais - de exercício da soberania, considerando as pressões heteronômicas a que fizemos referência anteriormente. Por fim, quanto à prestação de contas, a França conta com uma Cour des Comptes, equivalente ao Tribunal de Contas da União no Brasil, e com objetivos bastante próximos: subsidiar o Parlamento na aprovação ou não das contas públicas, a partir de relatórios consubstanciados globais ou parciais e pareceres.

O ciclo orçamentário francês tem duração de três anos, envolvendo o DOB (Débat d'Orientation Budgétaire), que inicia no Parlamento em junho no ano anterior ao exercício, e gera a apresentação pelo executivo do PLF (Projet de Loi de Finances) em outubro, culminando com a aprovação em dezembro da LFI (Loi de Finances Initiale). No ano de exercício o orçamento é executado, mas existe a possibilidade de propor retificações ao orçamento, por meio da apresentação ao Parlamento de uma LFR (Loi de Finances Rectificative). Concluída a execução, há a LR (Loi de Règlement), que mostra o montante definitivo de despesas e receitas e fecha o ciclo (Didier, 2011, p. 11; Baslé, 2004). Esta última é equivalente ao

30. Vimos mostrando essa dinâmica a partir das pesquisas desenvolvidas no âmbito do Grupo de Estudos do Orçamento Público e da Seguridade Social (GOPSS), acompanhando o Orçamento Geral da União desde o ano de 1997. Conferir: Behring, 2008b. Ver também: publicações de Análise da Seguridade Social da Anfip, disponíveis em: <http://www.anfip.org.br/> e Boschetti e Salvador, 2006. 
Balanço Geral da União (BGU) e esses são os documentos base para o trabalho dos tribunais de contas dos dois países.

Ambos os ciclos orçamentários são mistos, propostos pelo Executivo e aprovados pelo Legislativo com suporte do Tribunal de Contas, e possuem uma dinâmica anual semelhante: a LDO equivalendo ao DOB, mas com característica de Lei; a Lei Orçamentária Anual equivalendo à LFI, inclusive com a possibilidade de mudanças retificadoras; e o BGU equivalendo à LR. Porém o ciclo orçamentário brasileiro tem alguns traços diferentes, quando comparado ao francês. A Constituição de 1988 introduziu o Plano Plurianual (PPA), que envolve um planejamento dos investimentos públicos e metas físicas por um período de quatro anos, orientando a formulação das leis anuais. Apenas recentemente, em função de exigências da União Europeia (EU), a França introduziu no ciclo orçamentário uma Loi de Programmation des Finances Publiques, com vigência de quatro anos e que orienta a construção dos ciclos anuais e a análise da prestação de contas (Cour de Comptes, maio 2011). A existência dos já referidos orçamento fiscal, da seguridade social e das estatais, e de um volume maior de programas, desagregados em níveis ainda menores de alocação de recursos torna o orçamento público brasileiro mais complexo. Pensamos que houve no Brasil uma louvável busca no texto constitucional de associar planejamento, orçamento e continuidade de ações, num país que precisa induzir esse processo pela dificuldade de enraizamento do sentido de público em sua burocracia e na sociedade - em especial se consideramos que a Constituição de 1988 marca o fim de vinte anos de opacidade da ditadura militar-civil. Mas, ao mesmo tempo, permanece grande a fragmentação dos recursos, o que torna árduo o acompanhamento orçamentário, mesmo com os avanços tecnológicos no nível federal e em alguns entes federativos subnacionais. ${ }^{31}$

Para os objetivos deste estudo, tendo em vista realizar reflexões sobre a alocação do fundo público, com destaque para os gastos sociais, no Brasil e na França, vamos observar o ano de exercício de 2010 nos dois países, analisando suas prestações de contas nacionais, a partir das grandes linhas, ou seja, das missions e das funções, que indicam tendências gerais do gasto público. Evidentemente não é possível estabelecer correlações a partir de valores correntes, consi-

31. Os estados e municípios brasileiros não têm a mesma transparência do Orçamento da União, o que torna bastante difíceis os caminhos das pesquisas nesses níveis da federação. Vale lembrar que apenas em 2002 o conjunto dos municípios brasileiros passou por força legal a adotar o ciclo constitucional, aqui apresentado. 
derando que não trabalhamos aqui com o poder de compra das respectivas moedas no período estudado. Estabelecemos termos de comparação possíveis entre percentuais, utilizando o euro $(€)$ como referência, ou seja, convertendo os valores correntes em reais para o euro. Analisaremos os dados levantados sobre a execução orçamentária no ano de 2010, a partir dos percentuais em missions e funções mais importantes e comparáveis entre si, como parte do gasto total efetivamente alocado no ano de exercício de 2010 pelo Estado Nacional e administração da Sécurité Sociale - Régime Générale (França) e pela União (Brasil), considerando Orçamento Fiscal e da Seguridade Social, sendo que este último engloba o Regime Geral da Previdência Social (trabalhadores do setor privado). Assim, é importante deixar claro que não estamos considerando a alocação de recursos dos entes subnacionais, o que tem algumas implicações, a exemplo da saúde, da assistência social e da educação no Brasil, bem como em aide e action sociale, entre outras, na França, que recebem recursos importantes dos entes federativos subnacionais, ainda que esse fato não altere grandes tendências, cuja identificação é o que perseguimos neste estudo. Não estamos considerando também regimes especiais de previdência e do funcionalismo público nos dois países, mas o regime geral, que ademais reúne a maior parte dos recursos públicos em Previdência Social (assurance) nos dois países. Analisemos, então, as Tabelas 1 e 2, nas páginas seguintes.

A Tabela 1 considera a execução orçamentária do ano de 2010, tomando como fontes os dados da LR, a análise da Cour de Comptes (maio de 2011) e documentos oficiais sobre a prestação de contas da Sécurité Sociale - Regime Géneral, na França, com destaque para Les Chiffres Clés de La Sécurité Sociale 2010 (Drees, 2011). No Brasil, trabalhamos com os dados sistematizados no Balanço Geral da União - BGU (Orçamento Fiscal e da Seguridade Social), a análise do TCU e outros documentos complementares, para mostrar o peso de determinadas despesas do orçamento nacional, comparáveis entre os dois países, sempre considerando os valores efetivamente despendidos no ano, ou seja, os Crédits de Paiements sur factures (CP) na França, e as Despesas Realizadas (Brasil). Realizamos o esforço de reunir despesas que equivalem a um mesmo universo nos dois países, de forma que, no caso francês, somamos o orçamento do Estado (fiscal), de $€ 412,6$ bilhões e o da Sécurité Sociale - Regime General, de $€ 306,5$ bilhões, que não aparecem assim reunidos nas contas nacionais, ao contrário das contas brasileiras. A Tabela 2 relaciona os mesmos dados com o PIB dos dois países do ano de 2010, de forma que podemos vislumbrar o gasto público como parte da riqueza nacional. Este dado 
é importante porque reflete a parte da riqueza nacional que é investida em determinados eixos, dizendo sobre o nível de cobertura socializada das necessidades sociais e sobre a apropriação da riqueza nacional pelas classes e seus segmentos. A partir dos dados sistematizados nas duas tabelas, podemos desdobrar algumas considerações analíticas.

A primeira é de natureza geral e um tanto óbvia: apesar de alguns dados quantitativos serem aparentemente próximos — há uma diferença de cerca 100 bilhões de euros entre um orçamento e outro (a mais para a França), após a conversão do orçamento brasileiro para o euro - não se pode perder de vista que o impacto do gasto público francês será maior, considerando o tamanho da população, o grau de consolidação das políticas públicas, de estabelecimento de acordos com os partenaires sociaux (empregadores e trabalhadores), ${ }^{32}$ e de continuidade administrativa. Se calcularmos o volume de recursos orçamentários per capita investidos na França e no Brasil em 2010, chegamos ao valor de $€$ 11,2 mil (França) para $€ 3,5$ mil (Brasil), ou seja, a França investe aproximadamente três vezes mais que o Brasil por habitante. Mas esse é um dado muito geral, pois não revela efetivamente a quais segmentos se destinam os recursos. Para extrair elementos menos superficiais precisamos nos aproximar mais dos dados.

Nossa atenção volta-se então para o peso da dívida pública nos orçamentos dos dois países. A relação dívida/PIB tem sido um importante indicador de saúde econômica nacional, sobretudo quando se trata de fornecer indicadores ao mercado financeiro e aplicar políticas de austeridade, justificadas em nome do controle dos gastos públicos por organismos como FMI ou Banco Mundial. A relação dívida/PIB da França, em 2010, encontrava-se na marca de 82,3\% e saltou para 86\%, em 2011 (Eurostat, 11/6/2012). Esse mesmo indicador para o Brasil foi, segundo o Relatório do TCU sobre o ano-exercício de 2010, de 55\%, considerando o conceito de Dívida Bruta do Governo-Geral (envolvendo União, estados e municípios, mas excluindo estatais e o Banco Central), e de 40,3\% conforme o conceito de Dívida Líquida do Setor Público (envolvendo apenas a União sem as empresas estatais federais). Outros números sobre o Brasil aparecem considerando conceitos diferenciados: 78\% em 2011, segundo a Auditoria Cidadã da Dívida; ${ }^{33}$ 66,1\%

32. O termo, muito utilizado no debate francês — acadêmico e midiático — sobre a política social, refere-se ao conjunto de organizações envolvidas na gestão da mesma e em mesas de negociação. No caso da Sécurité, trata-se das organizações patronais e dos trabalhadores, bem como do Estado.

33. Conferir: Os números da divida (Fattorelli e Ávila, 2012). 


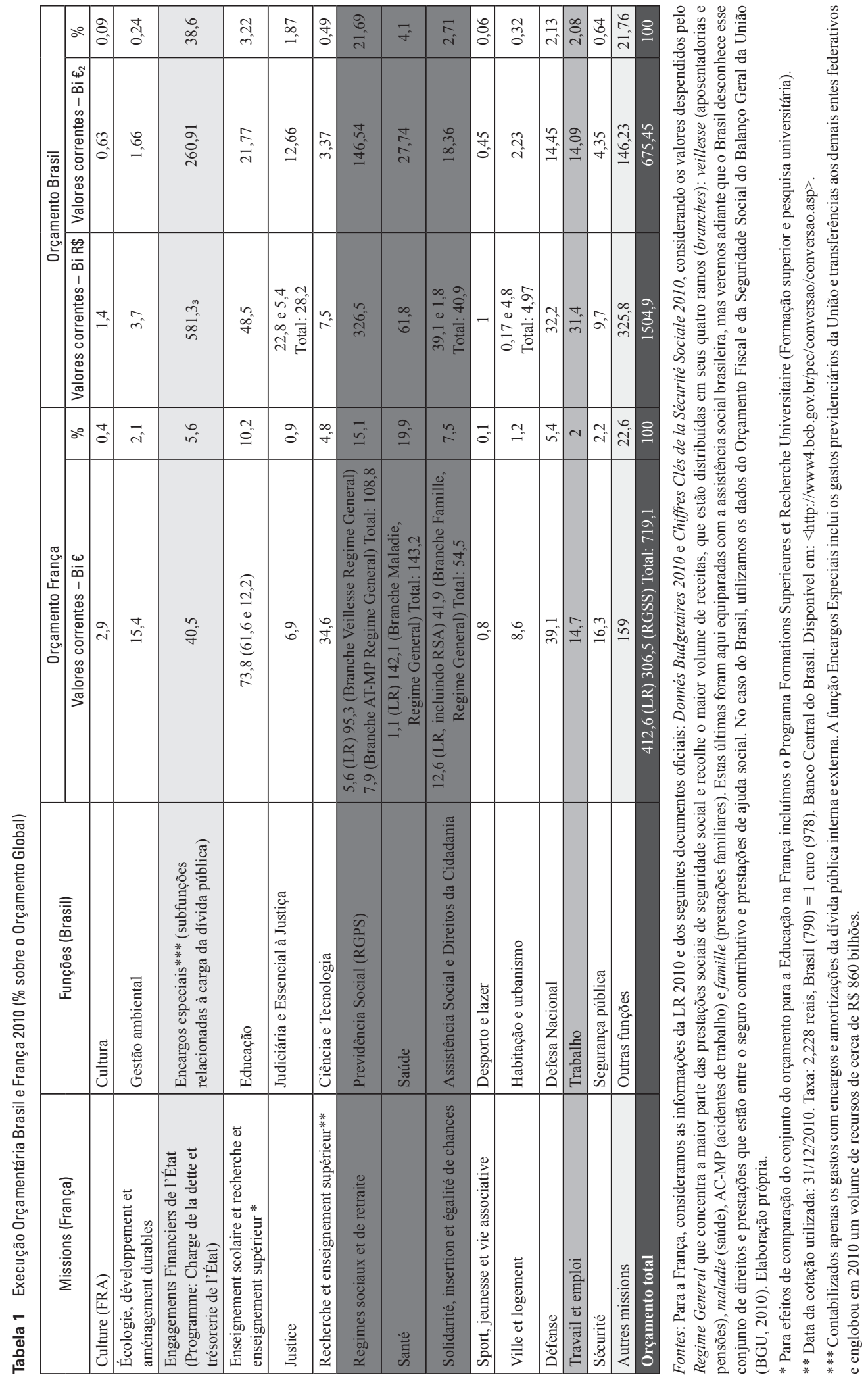




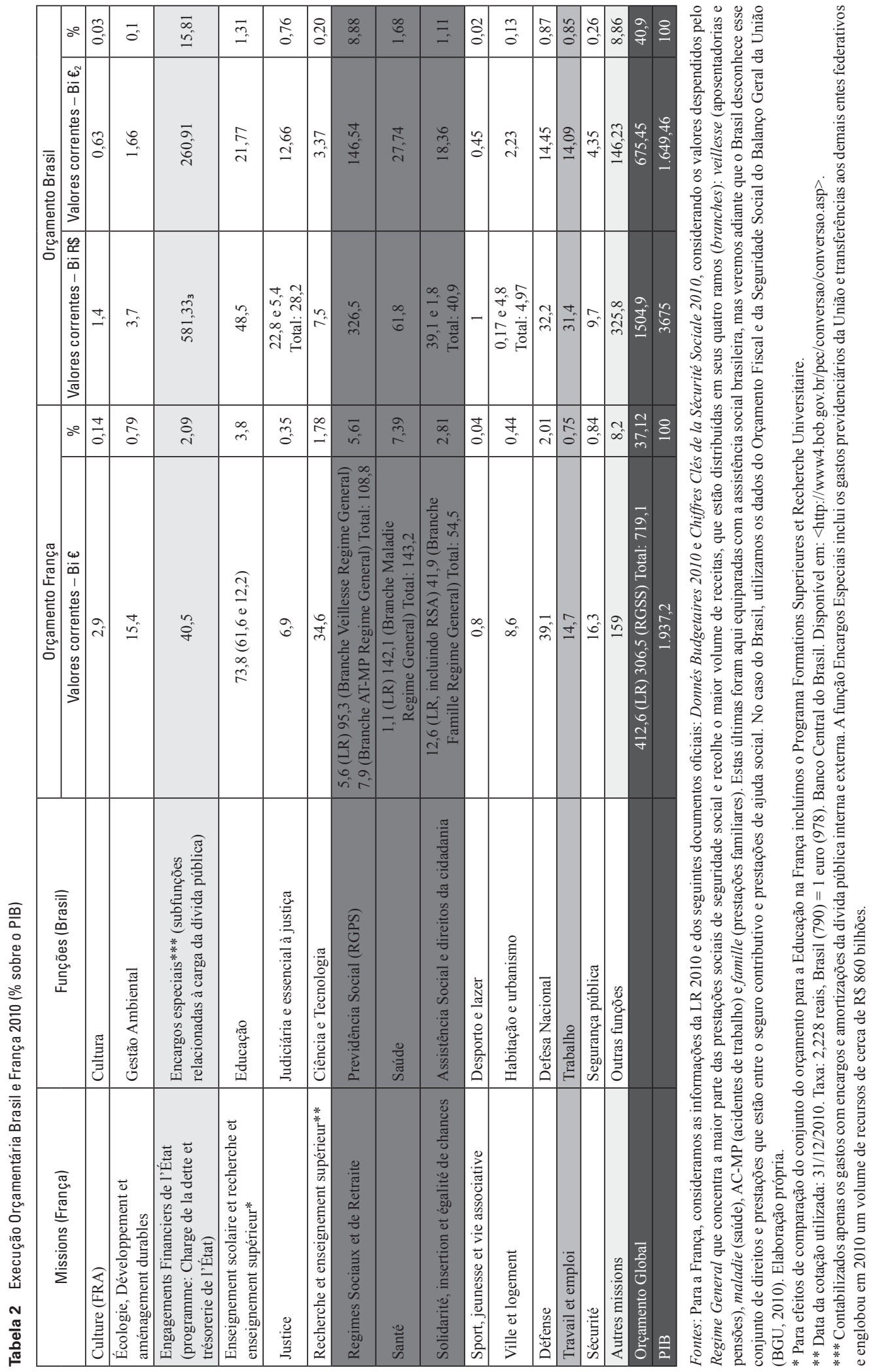


em 2010, conforme o FMI; ${ }^{34}$ e 40,2\% conforme estudo da OCDE $^{35}$ e declarações do governo na imprensa, provavelmente referindo-se ao segundo conceito citado pelo TCU. Como se pode identificar, são índices díspares e que revelam um problema de falta de consenso e de transparência do dado. Porém, a questão central é: apesar de a saúde econômica brasileira apresentar-se, segundo todos os índices, aparentemente melhor, o país canaliza $38,6 \%{ }^{36}$ de seus recursos orçamentários para o pagamento de juros, encargos e amortizações da dívida pública, considerando na função "Encargos especiais" as subfunções que se referem aos "Serviços das dívidas interna e externa" e ao refinanciamento de ambas (Tabela 1). Como proporção do PIB, trata-se de um comprometimento de 15,81\%, em 2010 (Tabela 2), ano em que o PIB teve um alto e atípico crescimento de 7,5\%, dando a impressão de que o Brasil passaria incólume à crise, o que não se confirmou na sequência, quando voltou a um crescimento do PIB em torno de 2,7\%, em 2011 (TCU, Relatório Ano-Exercício 2011).

A França realizou um dispêndio de 5,6\% de seu orçamento público quanto aos seus compromissos com a dívida no mesmo ano de 2010 (Tabela 1), o que representou 2,09\% do PIB (Tabela 2). No Brasil, os encargos com a dívida são o primeiro item do gasto público, estando à frente da seguridade social. $\mathrm{Na}$ França, estes passaram a ser o segundo maior item no gasto fiscal (Orçamento do Estado), depois da educação nacional. Se incluímos a Sécurité Sociale Regime General, os encargos com a dívida caem para o quinto lugar. Mesmo assim, a evolução do endividamento e seu peso no gasto fiscal causam preocupação e inquietação na França, onde também existem movimentos organizados em torno da auditoria da dívida pública, especialmente no que diz respeito às ope-

34. FMI, Perspectives de l'Économie Mondiale. Reprise, Risques et Réequilibrage, out. 2010.

35. OCDE, Estudos Econômicos da OCDE Brasil, out. de 2011. Disponível em: <http://fgvprojetos.fgv. br/sites/fgvprojetos.fgv.br/files/Overview\%20Brasil\%202011\%20\%28port\%29_1.pdf>. Acesso em: 11 jun. 2012.

36. Publicação da Auditoria Cidadã da Dívida estimou para 2010 um peso da dívida no orçamento público de 44,93\% (Informativo da Auditoria Cidadã da Dívida, Brasília, 2011), maior que o dado aqui encontrado. No entanto, vamos operar aqui com o dado a partir das fontes oficiais, o que não altera as tendências que vamos apontar. Esta importante organização tem realizado um trabalho incansável de esclarecimento e denúncia do odioso endividamento brasileiro. Seu cálculo da relação dívida/PIB considera juros, encargos, amortizações e a rolagem da dívida, o que implica um dado maior que o oficial sobre essa relação, mas que torna mais transparente o peso do endividamento do país. Cabe esclarecer ainda que a função "Encargos especiais" engloba outros gastos, a exemplo das transferências constitucionais a estados e municípios, que não entraram nessa conta. 
rações de salvamento das instituições bancárias na sequência do estouro da crise, em 2008 (Chesnais, 2011).

Estes números nos mostram que a França e o Brasil estão envolvidos no processo global de punção do fundo público pelo capital financeiro (Behring, 2010), mas em escalas e com patamares elevadíssimos de comprometimento dos recursos orçamentários diferentes e com impactos também diferenciados na sociabilidade. Ou, melhor dizendo: níveis desiguais de socialização dos custos desse processo. A França, ao que tudo indica, realiza uma gestão com maior soberania de sua dívida, dispondo de margens de manobra diferenciadas e maiores, inclusive porque compõe os núcleos decisórios das instituições multilaterais, com relações viscerais com os credores. Outro aspecto que possivelmente corrobora para essa margem maior de manobra é a natureza da dívida francesa, de médio e longo prazo, e menos sensível à especulação, em que pese as agências de notação de risco desferirem duros golpes sobre o país no último período, amplamente divulgados na imprensa. Um registro fundamental é o de que a França não pratica taxas de juros escorchantes: as taxas de juros estiveram em 2010 fixadas em $0,75 \%$ em curto prazo, e em 3,11\% em longo prazo. ${ }^{37}$ Essa mesma orientação não se aplica aos países periféricos, dentre os quais o Brasil, que vem mantendo taxas anuais de juros em patamares elevadíssimos para manter seus níveis de atratividade dos capitais, com forte impacto na dívida pública e privada. As taxas de juros oscilaram, em 2010, entre 8,65\% (janeiro de 2010 ) e $10,66 \%$ (dezembro de 2010). ${ }^{38}$

A França não compromete, tão intensa e diretamente como no Brasil, o financiamento da Sécurité Sociale e de outras políticas públicas nesse processo de favorecimento ao rentismo, ainda que destine um volume de recursos orçamentários significativo para esses segmentos. Por outro ângulo, é possível afirmar que há um comprometimento indireto, a uma visível erosão e decadência de políticas públicas antes consistentes, bem como aprofundamento da desigualdade nos acessos antes concebidos para ser universais. Há estudos que mostram o impacto das políticas neoliberais na França, ainda que talvez seja o país que mais resistiu a essas políticas. Vejamos alguns elementos que ilustram os impactos em importantes políticas públicas. A França adotou uma política, no contexto da contrarreforma do Estado, de

37. Insee, Taux d'intérêt à court et à long terme par pays. Disponível em: $<$ http://www.insee.fr/fr/themes/ tableau.asp?ref_id=CMPTEF08205\&reg_id=98>. Acesso em: 11 jun. 2012.

38. Conferir Banco Central do Brasil, Histórico das Taxas de Juros. Disponível em: <http://www.bcb. gov.br/?COPOMJUROS>. Acesso em: 11 jun. 2012. 
não substituição dos funcionários aposentados na proporção de um para cada dois, extinguindo postos públicos de trabalho em nome do gerenciamento dos custos de pessoal para diminuir o déficit público. A Cour de Comptes (2011) pondera sobre a eficácia dessa política, mas não pelo aspecto que vem sendo sinalizado nas análises mais críticas: sua preocupação é com a não ocorrência das aposentadorias previstas e a ausência de uma política coordenada com as remunerações. Do ponto de vista do acesso aos serviços públicos, o impacto dessa medida foi, por exemplo, a supressão, entre 2007 e 2012, de 80 mil postos de trabalho no ensino escolar, o que se tornou uma questão candente no debate das recentes eleições presidenciais. Numa clara combinação com o processo de empobrecimento da população, e sinal de que as políticas de proteção em curso não estão conseguindo fazer frente de forma suficiente, há na França o reaparecimento de focos de doenças erradicadas, a exemplo da tuberculose em Clichy-sous-Bois, noticiado em tom de denúncia pelo Le Monde (29/9/2011). Nesse mesmo mês, o Le Monde (21/9/2011) sinalizava um aumento de 4,6\% do número de detentos no sistema carcerário - em torno de 63.602 pessoas em 2011, segundo o jornal. Mas a questão que chama a atenção nessa matéria é a diminuição do número de funcionários públicos e suas condições de trabalho, considerando o aumento da demanda, que mostra a face da criminalização dos pobres. Outra questão em foco no país é a moradia. Estudo da Fondation Copernic (2012) mostra que a França vive uma espécie de boom de especulação imobiliária desde 2000, com uma alta dos preços dos aluguéis em torno de 118,2\% que não foi acompanhada pela renda das famílias dos locatários. O resultado foi um crescimento de $96,6 \%$ no número de expulsões de famílias de habitações entre 2000 e 2010. O mesmo estudo mostra os superlucros do setor imobiliário, que cresceram muito acima da evolução do PIB e foram alimentados também por medidas fiscais favorecendo o setor. ${ }^{39}$ A Cour de Comptes recomendava, em fins de 2011, um aporte de recursos de urgência para os sem teto (Le Monde, 16/12/2011), criando mais vagas sociais nas zonas urbanas sob forte tensão. Enquanto isso, os movimentos sociais denunciam a existência de 2,12 milhões de habitações vazias, dado oficial do Insee, o que mostra a falta de aplicação da lei de requisição e também o desengajamento financeiro do Estado, a partir do baixo financiamento da habitação social e das alocações de habitação. De fato, observa-se na Tabela 1 que a Mission Ville et Logement consome apenas 1,2\% da despesa pública francesa, o que corresponde a apenas $0,44 \%$ do PIB. Ainda assim, o aporte público é maior

39. Estes e outros dados podem ser encontrados em: <www.contrelelogementcher.org>. 
que no Brasil, onde os percentuais são $0,32 \%$ do orçamento e $0,13 \%$ do PIB e existem políticas bastante residuais, mesmo com seu gigantesco déficit habitacional, uma das razões de existência das conhecidas favelas brasileiras e de um sem-número de habitações chamadas subnormais.

Em que pese esses impactos, a França não implementa o superávit primário como o Brasil, onde as consequências são evidentemente mais dramáticas. O Solde Budgétaire Primaire (SBP) é um parâmetro econômico e não uma obrigação a ser cumprida a qualquer custo, mesmo com os draconianos indicadores de sustentabilidade da Commission Européene (Elbaum, 2011, p. 455-457). O saldo primário da França vem se deteriorando tanto quanto o saldo global (Cour de Comptes, 2011, p. 34), mas não implica uma escolha política de deliberadamente produzir um saldo positivo para sinalizar ao mercado condições de pagamento de dívida. Um mecanismo tão perverso como a Desvinculação de Receitas da União (DRU) não existe na França. A DRU alimenta o superávit primário no Brasil, retirando $20 \%$ das receitas de impostos e contribuições sociais, sendo que estas últimas financiam a seguridade social (para além das cotizações de empregados e empregadores), para compor as reservas nacionais ou pagar diretamente juros e encargos da dívida que estão expressos neste percentual de $38,6 \%$ do orçamento federal. São medidas injustas e lesivas, que vêm sendo adotadas no Brasil desde o acordo com o FMI de 1999 (caso do superávit primário), e desde o Plano Real (1994), quando foi criado o Fundo Social de Emergência, depois Fundo de Estabilização Fiscal, e hoje, DRU, mecanismo cujo único objetivo - ainda que a legislação que a regula aponte outros itens - tem sido o de garantir reservas cambiais que assegurem os compromissos com os credores nacionais e internacionais, que especulam com o risco-país atribuído pelas agências de notação de títulos, ${ }^{40}$ de forma que qualquer alteração nessa arquitetura perversa produz fortes abalos na vulnerável economia política brasileira (Filgueiras e Gonçalves, 2007).

Destacamos ainda outros dados para análise. As despesas com educação e pesquisa científica são centrais, já que são estruturantes para a autonomia de qualquer país, haja vista o acesso à informação, a formação da força de trabalho e, muito especialmente, o lugar das patentes na economia mundo (Chesnais, 1996). A França alocou 10,2\% de seu orçamento nacional em educação, considerando aqui os três níveis de ensino e 4,8\% em pesquisa (com recursos para as universidades e

40. Para uma leitura crítica do papel dessas agências mantidas pelo grande capital financeiro e o impacto de sua consultoria na economia-mundo, consultar Chesnais, 2011; Didier, 2011 e Lordon, 2008. 
centros de pesquisa), ou seja, esses dois itens reunidos englobam $15 \%$ do investimento público (Tabela 1) e envolvem 5,78\% do PIB (Tabela 2). O Brasil destinou $3,22 \%$ dos recursos orçamentários federais para a educação e $0,49 \%$ para ciência e tecnologia, o que resulta em 3,71\% da despesa total do ano de 2010 (Tabela 1), que equivale a $1,51 \%$ do PIB nas duas rubricas (Tabela 2). Enquanto a França gasta duas vezes mais com educação e ciência e tecnologia que com a dívida pública, o Brasil gasta dez vezes menos com educação e ciência e tecnologia, em comparação com os encargos da dívida. Além do evidente reforço da heteronomia brasileira, esse elemento significa mais duas constatações sobre o Brasil: a condenação à condição de dependência e hipoteca de seu futuro, bem como o enorme campo aberto para a mercantilização da educação, diretamente relacionado à baixa oferta da educação pública. Na verdade, é a oferta privada que cresce exponencialmente, o que aponta um grave problema de acesso, sobretudo ao ensino secundário e universitário. Existe mercantilização da educação em curso também na França de hoje em uma escala que não tivemos condições de aferir, mas que é visível nos grandes centros urbanos, em geral articulada à empregabilidade, e que atinge, sobretudo, o ensino superior, após os acordos de Bolonha. Como dissemos, essa é uma marca de período e que se relaciona aos processos de supercapitalização analisados por Mandel (1982). No entanto, o baixo grau de oferta pública no Brasil, corresponde a um boom da oferta privada, muitas vezes de baixa qualidade, especialmente nos níveis médio e superior. Portanto, se a mercantilização é um processo que entrelaça os dois países, a oferta pública nesse campo os diferencia absolutamente, já que na França a escalada da mercantilização na educação permanece sendo residual e encontra fortes resistências. Podemos chamar a atenção também para o gasto com a cultura. Os valores são baixos para os dois países, mas ainda assim a França investe o triplo dos recursos alocados no Brasil: 0,4\% do orçamento e $0,14 \%$ do PIB, na França; e $0,09 \%$ do orçamento e $0,03 \%$ do PIB no Brasil. Evidentemente, os bens culturais sem o suficiente aporte público são apropriados pela indústria cultural e por dinâmicas privatistas e do espetáculo nos dois países, o que inclui renúncia fiscal para os mecenas da arte, dentre os quais muitas instituições financeiras. No caso específico da França, o enorme fluxo do turismo cultural e uma dinâmica de produção cultural muito consolidada permitem, a partir do pagamento de taxas, receitas de manutenção do imenso e impressionante patrimônio artístico e cultural do país. No Brasil, são bastante conhecidas as dificuldades de conduzir uma política cultural consistente e que apoiem a cultura popular - que 
ademais possui um componente de resistência no país - e mantenham o patrimônio histórico, artístico e cultural num país de dimensões continentais.

Se observarmos ainda a questão militar, veremos que esse também é um elemento a ser comentado no gasto público dos dois países. Pelo seu lugar na geopolítica mundial, além da questão dos territórios de ultramar, herança do colonialismo, a França destina 5,4\% de seu orçamento para a defesa. Já o Brasil destina 2,13\% de recursos nessa rubrica, ou seja, duas vezes menos recursos, ainda que a participação brasileira nas mobilizações de forças internacionais tenha crescido (Tabela 1). Como parcela do PIB dos dois países, temos que a França destina 2,01\%, e o Brasil, 0,87\% (Tabela 2). Exemplo desse novo lugar do Brasil é a presença de forças brasileiras no Haiti há oito anos e seu esforço diplomático para compor o Conselho de Segurança da ONU. Mas essa participação ainda pode ser considerada residual frente à presença francesa no Afeganistão, dentre outras guerras localizadas, muitas delas relacionadas desde 2001 ao ambiente de "guerra ao terrorismo" induzido pela política norte-americana, com o apoio do G7.

Por fim, um breve comentário sobre a questão ambiental. No exato momento em que escrevemos estas linhas acontece no Brasil a Conferência Rio +20, onde se constata que apenas quatro das noventa metas ambientais do planeta obtiveram avanços nos últimos quarenta anos (Carta Capital, 12/6/2012). Pois bem, nesse contexto, a França destinou no ano analisado 2,1\% (Tabela 1) de seus recursos para a ecologia e o desenvolvimento sustentável, o que significou um percentual de 0,79\% do PIB (Tabela 2). O Brasil, com a responsabilidade ambiental de dispor de uma floresta tropical como a Amazônia e de um dos maiores reservatórios de água do mundo, investe na gestão ambiental $0,24 \%$ do orçamento (Tabela 1), o que implica $0,1 \%$ do PIB (Tabela 2). São cifras pífias nos dois países se pensarmos na importância da questão para a humanidade (Löwy, 2011). Se comparadas com o volume de recursos capturados pelo luxo dos burgueses, especialmente sua fração rentista, vemo-nos diante da racionalidade perversa do valor, da expropriação, da apropriação privada da riqueza que hoje envereda por uma lógica destrutiva que pode levar a caminhos sem retorno. Tal racionalidade, ademais irracional, ${ }^{41}$ se expressa no orçamento dos estados nacionais, quando destinam um insignificante volume de recursos para a questão ambiental, a exemplo da França e do Brasil.

41. Goya diz numa de suas mais importantes gravuras que o sono da razão produz monstros. Ele fazia um triste libelo contra a guerra, mas pensamos que a frase aqui se aplica perfeitamente. 
Do ponto de vista da receita, na França, as principais fontes do orçamento do Estado são, por ordem de importância: a TVA (taxa sobre valor agregado), o Imposto sobre a Renda, Imposto sobre as Sociedades, Outras Receitas Fiscais e Taxas sobre Produtos Petrolíferos (Cour de Comptes, 2011, p. 90). A TVA, que correspondeu em 2010 a 50\% da arrecadação líquida, tem como característica o impacto no consumo, ou seja, é um imposto regressivo, o que é compensado pela capacidade extrativa sobre a renda, as sociedades e demais impostos. Este quadro de pesos se manteve proporcionalmente no projeto de Loi de Finances de 2012, conforme noticiava o Le Monde, em 29 de setembro de 2011. Do ponto de vista da Sécurité Sociale - Regime General, a receita advém, por ordem de peso em 2010: 59\% de cotizações sociais de empregadores (45\%) e empregados (45\%); $21 \%$ da CSG uma contribuição social que incide basicamente sobre a renda trabalhadores, em até 7,5\%, a partir de determinados patamares (Elbaum, 2011, p. 425); 11\% em impostos e taxas diversos (tabaco e álcool, por exemplo); $6 \%$ de transferências; e $3 \%$, outros. Trata-se de uma estrutura fiscal que incide fortemente sobre os trabalhadores, especialmente pelo crescimento da TVA e da CSG.

No Brasil, a estrutura fiscal está constituída em grandes agregados, segundo documento do Ministério da Fazenda (2011), que analisa o desempenho de 2010. O Orçamento Fiscal arrecadou 25,04\% dos impostos federais, na seguinte ordem de peso: Imposto de Renda 18,23\% (com destaque para pessoa física retido na fonte em 9,48\% e pessoa jurídica em 7,43\%); o Imposto sobre Produtos Industrializados (IPI), com 2,63\%; e o Imposto sobre Operações Financeiras, com apenas $1,82 \%$. Na sequência aparecem outros vários impostos que somam, no conjunto 2,36\% da arrecadação. Quanto ao orçamento da Seguridade Social, este arrecadou, em 2010, 37,28\% dos recursos federais, sendo as principais fontes: as contribuições de empregados e empregadores (17,24\%), a Cofins (10,99\%) e a CSLL $(4,13 \%)$. As demais fontes reúnem apenas $4,92 \%$ dos recursos. Como se pode observar, a Seguridade social arrecada mais que o orçamento fiscal no Brasil o que tem gerado mecanismos de transferência de recursos da seguridade para o orçamento fiscal, em especial para o pagamento de encargos da dívida, pesados como vimos, e constituição de reservas, via superávit primário.

Mas o que chama a atenção no conjunto dos destaques que fizemos acima é que a relação dívida/PIB brasileira é menor nos vários cálculos disponíveis. O que permite concluir que o impedimento da expansão da educação pública, do investimento de maiores recursos para a cultura e o desenvolvimento intensivo de tecnologias e da ciência no Brasil é sua condição na economia-mundo, subordinada do 
ponto de vista militar, de patentes e pelo endividamento ilegítimo e odioso. Enquanto a França, para além da capacidade de os trabalhadores franceses resistirem às investidas neoliberais mesmo na era Sarkozy, tem melhores condições estruturais e históricas de autodeterminação e soberania na geopolítica mundial. Retomaremos este elemento-chave na conclusão deste artigo.

Vejamos então, de forma mais detida, a questão do financiamento e as despesas de proteção social nos dois países.

\section{Financiamento da proteção e da Seguridade Social: elementos para reflexão}

A Sécurité Sociale (ou Sécu, como a tratam com intimidade os franceses) é o coração do padrão ou sistema de proteção social, mas não se confunde com ele. Desde o plano Laroque, de 1945, a França construiu um híbrido bastante original entre as fundadoras experiências bismarkiana (1883) e beveridgeana (1942), ${ }^{42} \mathrm{com}$ fortes raízes em sua história. Sendo herdeiro de muitas tradições, o sistema de proteção social francês nutriu-se de influências que passam pelas corporações de ofício e a Revolução Francesa (Duval, 2008, p. 46-7; Barbier e Théret, 2009, p. 19; Elbaum, 2011), parecendo perseguir até hoje objetivos beveridgeanos com métodos bismarckianos (Palier, 2005). Assim, o conceito de proteção social engloba um espectro amplo de instituições: o conjunto dos regimes de seguros sociais obrigatórios, dentre eles a Sécurité Sociale - Regime Generale, os regimes de seguro dos funcionários públicos, os regimes complementares de seguro, as previdências privadas, o seguro-desemprego e as intervenções sociais do Estado, o que inclui as prestações sociais, dentre elas para a habitação, e ações assistenciais. Este conjunto cobre os riscos de doença, envelhecimento, maternidade, emprego, moradia e pobreza. Embora as tentativas de construção dos tipos ideais de sistemas de proteção social tentem enquadrar a experiência francesa, a exemplo de seu encaixe no conceito de modelo corporativo-conservador por Esping-Andersen (1991), ela tem mostrado que as coisas não são tão simples. O pilar do seguro e do corporativismo (bismarckiano) tem se revelado um elemento de resistência às políticas neoliberais,

42. Para uma compreensão mais detalhada acerca destes dois grandes parâmetros históricos da proteção social, ver: Behring e Boschetti, 2006; Boschetti, 2006; e Boschetti, 2003 e o clássico Polanyi, 2000. 
apesar da existência de perda de generosidade do sistema (Barbier e Therét, 2009, p. 23), e participa da oferta do conjunto das prestações sociais, de tendência beveridgeana, ao lado do Estado. Por outro lado, o sistema de proteção social francês vem desenvolvendo uma espécie de capacidade adaptativa diferenciada, no contexto da onda longa de estagnação, gerando fontes fiscais de financiamento global e criando prestações e direitos, na perspectiva de acompanhar novas necessidades (ou riscos). Estes elementos fazem com que teses sobre o desmonte do Estado social, ou crise do Estado providência (Rosanvallon, 1981), que tiveram ressonância nos anos 1980, ou de uma contrarreforma tão profunda a ponto de aproximar esse padrão da experiência anglo-saxônica, sejam no mínimo discutíveis, apesar das perdas reais existentes (Duval, 2008).

Não há dúvida, portanto, sobre a natureza híbrida e compósita da proteção social francesa e de que a necessidade de acordos com os partenaires sociaux, articulada à cultura política e às lutas de rua - a proteção social é enraizada no imaginário coletivo e em comunidades políticas historicamente constituídas (Barbier e Therét, 2009, p. 24) - foram elementos de preservação de sua cobertura e especialmente de um espraiar residual dos processos de supercapitalização no campo dos seguros. Exemplo disso é que os fundos de pensão e as previdências privadas, que operam por meio de regimes de capitalização, com forte vínculo com os mercados financeiros, não tiveram crescimento destacado nesse país, onde representavam apenas $1 \%$ do PIB no final de 2007 , mesmo com a conversão dos socialistas ao monetarismo nos anos $1980,{ }^{43}$ que efetivamente fragilizou os processos de resistência, ainda que sua presença tenha feito alguma diferença (Duval, 2008). Já em outros países da Europa, a exemplo dos Países Baixos, com 179\%, e Reino Unido, com 79\%, e nos Estados Unidos, 77\%, esse crescimento foi estrondoso. Mantiveram-se na França os regimes por repartição e a solidariedade intergeracional quanto às aposentadorias, ou seja, a França claramente recusou a estratégia da capitalização, fazendo com que hoje tenha melhores margens de manobra para manejar os efeitos da crise, seja no campo das coberturas sociais, seja no campo

43. Para compreender a conversão socialista e certa reprodução uníssona de determinados axiomas na esquerda e na direita francesas, conferir a interessante pesquisa de Hartmann (2011), que mostra os processos de formação e de circulação internacional das elites políticas europeias, a qual tivemos a oportunidade de conhecer em seminário realizado no Cresppa-CSU, em 24/1/2012. No caso francês, Hartmann constata grande homogeneidade e concentração desse processo de formação, nas grandes escolas de elite e de pequeno porte. No caso dos quadros da administração pública, $80 \%$ desta é recrutada numa pequena reserva, tem origem burguesa ou pequeno-burguesa, com forte predominância de Paris. 
dos riscos financeiros relacionados à dinâmica da previdência complementar por capitalização (Cornilleau et al., 2010, p. 35; Boschetti, 2012).

Embora seja fundamental explicitar o conceito de proteção social para compreender melhor os desenvolvimentos da política social na França, não vamos adotá-lo globalmente como o campo empírico da pesquisa, ${ }^{44}$ no sentido de perseguir a perspectiva comparada de universos conceitualmente mais próximos. Para esse objetivo, cabe delimitar a Seguridade Social como universo que possui na França e no Brasil características semelhantes. Ademais, segundo Barbier e Théret (2009), a Sécurité Sociale absorvia, em 2006, 80,8\% das despesas de proteção social e $83,1 \%$ do conjunto das prestações sociais.

A Sécurité Sociale, portanto, é um pilar decisivo do sistema de proteção social francês, cobrindo grandes riscos relacionados ao trabalho, já citados anteriormente, na maior parte das vezes sob a forma do seguro. Trata-se de um conjunto institucional complexo e fragmentado, porém unificado. Sua unidade de base é o regime, e existem hoje no país mais de quinhentos regimes, ainda que a maior parte da população esteja vinculada ao Régime General, que engloba o conjunto dos trabalhadores do setor privado (como no Brasil) e que estará no centro de nossa análise adiante. Estes regimes são geridos por caixas, sob tutela do Estado, e que possuem representação dos partenaires sociaux, que efetivamente decidem sobre seus rumos e realizam cotidianamente a gestão dos recursos. A Sécurité Sociale é dividida em quatro grandes ramos (branches): família, envolvendo as prestações familiares; seguro-doença (saúde); acidentes de trabalho; e seguro-velhice, relacionado às aposentadorias e pensões. $\mathrm{O}$ funcionalismo público possui regimes especiais, processo que advém também do espírito republicano da Revolução Francesa, que atribuía à função pública um lugar diferenciado. O seguro-desemprego é gerido por uma caixa própria pelos partenaires sociaux, a Unedic, cujos aportes de recursos são assegurados pelo Estado e pela Sécurité Sociale — Regime General, com 99\% em cotizações de empregados e empregadores, com maior peso para esses últimos, segundo Elbaum (2011, p. 420). No entanto, há importante aporte de recursos para

44. Mesmo porque os estudos franceses parecem não ter chegado a um consenso sobre os universos englobados pelos conceitos de Estado Social, Proteção Social e Seguridade Social. Há momentos em que os dois primeiros são utilizados num sentido mais amplo, mas não fica clara a razão de não constituírem o mesmo universo (Elbaum, 2011). Há outros em que os dois últimos parecem constituir o mesmo universo (Barbier e Therét, 2009). Para efeito deste estudo, que não pretende esgotar um debate que parece estar longe do fim, vamos delimitar o campo da Sécurité Sociale - Regime General, tomando como referência a prestação de contas oficial, segundo a LFSS, mas em diálogo com estes e outros autores. 
políticas relacionadas ao desemprego, ou de ativação do emprego e formação profissional, na Mission Travail et Emploi, como pudemos constatar a partir da síntese de Aubin (2011, p. 71-86).

O outro pilar da proteção social francesa e que deve ser considerado no campo empírico deste estudo, levando em conta a correlação com o conceito brasileiro de Seguridade Social, é a ajuda e a ação sociais, que poderia ser equiparado ao que chamamos no Brasil de assistência social, ${ }^{45}$ mas com algumas precauções. Isto porque, na França, há um conjunto de direitos muito diversificado, envolvendo prestações sociais e ações, financiado pelo orçamento fiscal, mas também pela Sécurité Sociale, e gerido na maior parte das vezes pelos entes federativos subnacionais (Départements e Communes), ${ }^{46}$ distribuídos em 27 regiões. Os chamados mínimos sociais na forma de transferência de renda são distribuídos pela Sécurité Sociale, ainda que financiados pelo orçamento fiscal. Este segmento da proteção social francesa consumia cerca de 10\% das receitas fiscais, em 2006 (Barbier e Théret, 2009, p. 12). O Brasil não conhece um sistema de prestações familiares como o francês, que envolve habitação, educação primária, a exemplo de suportes para material escolar no início do ano letivo, entre inúmeras outras necessidades reconhecidas como direitos. Estas prestações são financiadas pelo Estado e pelas cotizações e poderiam estar classificadas exatamente entre o seguro e a assistência. Vão, portanto, muito além da transferência de renda assistencial — que ademais é muito mais consistente na França que o Bolsa Família brasileiro, e dos serviços sociais mais ou menos complexos, que no Brasil correspondem ao Suas. Tendo em vista a dificuldade comparativa aqui, optamos por relacionar a branche famille (ramo família) e a mission Solidarité, insertion et égalité de chances com a função Assistência Social no Brasil, mas com plena consciência de que os conceitos sob os números são neste caso muito diferentes, ao contrário da Saúde e da Previdência Social.

Além da Sécurité Sociale e da ajuda e ação social, há sistemas mutuais e de previdência privada facultativos e voluntários e, a princípio, com fins não lucrativos.

45. Há uma forte rejeição do termo assistência social no debate francês, renomeada aide sociale desde 1953 (Barbier e Théret, 2009, p. 86). Na interpretação corrente neste país, o termo assistência social remete à indignidade e à ausência do direito. Porém, eventualmente, os autores se referem a este ramo da proteção como assistência, a exemplo de Elbaum (2011). Essa relação tensa, de rejeição e interpenetração, entre assistência e previdência, fundada na condição do trabalho, é analisada em Boschetti (2003 e 2006).

46. O equivalente aos estados e prefeituras no Brasil. A França conta hoje com 36.781 Communes, e 101 Départements, incluindo os territórios de ultramar. 
São herdeiros das estruturas mutualistas do século XIX e assumem um papel crescentemente importante no campo da saúde. Os autores franceses são bastante cuidadosos ao qualificar esse setor como privado, já que há presença de grandes mutuais de funcionários públicos. Contudo, é evidente que existem no último período fortes pressões do capital financeiro para uma participação maior no sistema, considerando o volume de recursos que mobilizam, especialmente nessas grandes caixas do funcionalismo público e o apetite que estes despertam no mercado de capitais. Duval (2008, p. 40) mostra os esforços para introduzir uma dose de capitalização no sistema francês, especialmente na contrarreforma de 2003, com a criação dos planos de poupança-aposentadoria individuais (Perp) e coletivos (PPESVR), inclusive com incentivos fiscais. No entanto, conforme dado acima citado, vimos que seu impacto não é significativo. Esse campo não será considerado empiricamente, para efeito dos objetivos deste texto.

Sobre a questão do financiamento, é exatamente aqui que cabe falar de um sistema de proteção social, apesar da sua fragmentação institucional. A unidade e a cobertura universal do sistema são asseguradas pelo financiamento cruzado (Barbier e Théret, 2009, p. 15): há transferências de compensação entre Estado e regimes de seguro social, para garantir a cobertura, suprindo as crescentes necessidades de financiamento; e há uma espécie de solidariedade interprofissional, quando os cruzamentos se fazem entre os regimes de seguro social de categorias diferentes de trabalhadores. Essa migração permanente de recursos para assegurar a cobertura dos diversos direitos constitui uma efetiva solidariedade nacional. Assim, estão em permanente convivência duas lógicas: a do seguro e a da solidariedade nacional (Barbier e Théret, 2009, p. 15). Cabe lembrar que a Sécurité Sociale não faz parte do orçamento do Estado, sendo regida por legislação própria, a Lei de Financiamento da Seguridade Social (LFSS). Há previsão de recursos do orçamento fiscal nas Missions Santé e Regimes Sociaux e de Retraite, como mostram as Tabelas 1 e 2, mas como elemento complementar.

Do ponto de vista da receita, a maior parte dos recursos é assegurada pelas cotizações dos trabalhadores e empregadores fundamentalmente, ainda que nos últimos anos tenham sido criados mecanismos universais de financiamento, que transferem recursos orçamentários fiscais para sua sustentação. Barbier e Therét (2009) mostram que tem ocorrido uma diminuição da contribuição dos trabalhadores, em função da dinâmica do mercado de trabalho e especialmente do desemprego, acompanhado de certa constância com leve tendência de baixa da contribuição dos empregadores, o que vem sendo acompanhado pelo aumento do aporte de 
impostos e taxas especificamente criados para dar suporte à política social. Exemplo disso é a Contribution Sociale Généralisée (CSG), criada em 1991, e que incide sobre a renda em 7,5\% a partir de um determinado patamar (Elbaum, 2011, p. 425), e que não compõe o orçamento do Estado (LFI), mas da Sécurité Sociale (LFSS). A CSG cresceu em importância como mecanismo de financiamento da proteção social francesa, acentuando um lado beveridgeano de solidariedade nacional. Em 2010, a CSG financiou $21 \%$ da Sécurité Sociale, ao lado das cotizações (59\%), impostos e taxas, especialmente sobre tabaco e álcool (11\%), transferências $(6 \%)$ e outras receitas (3\%) (Drees, 2011). Essa composição mostra a importância crescente de impostos e contribuições em detrimento das cotizações. Apesar dos mecanismos de financiamento cruzado, a Sécurité Sociale vem mantendo um desempenho negativo, ou seja, na França também há um forte debate sobre o trou de la Sécu (déficit da Seguridade Social), especialmente com as orientações de Maastricht, segundo as quais os Estados nacionais devem manter um déficit público de, no máximo 3\%, do PIB, implicando verdadeiras batalhas políticas desde os anos 1990, onde o falso argumento da fatalidade demográfica (Duval, 2008, p. 35) é recorrentemente reivindicado para sinalizar a possível falência futura do sistema.

Nesse sentido, temos um ambiente bastante semelhante a envolver os dois países, pressionando pelo estabelecimento de tetos e controles das aposentadorias, haja vista a quantidade de publicações e matérias de mídia nesse sentido. Duval (2008) faz um interessante apanhado dessa dinâmica na França, criticando brilhantemente a transformação da Sécurité Sociale em uma questão técnica de equilíbrio de contas, cuja gestão deveria ser semelhante à empresa, quando na verdade se trata de uma questão de economia política e de escolhas políticas e sociais. Para o autor, este debate acontece no contexto de uma ofensiva ideológica que persegue o objetivo de mudar a percepção da proteção social. Desloca-se o conceito de necessidades de financiamento da Seguridade Social - necessidades geradas pela dinâmica de desemprego e baixa da renda no mundo do trabalho, que provocam queda das receitas combinada à alta das despesas, produzida pelo aumento das necessidades sociais - para a ideia de déficit. Tal deslocamento visa responsabilizar os direitos de Seguridade Social pelas dificuldades das finanças públicas e do investimento, mas também pelas deslocalizações e o desemprego, a partir do discurso corrente sobre o alto custo do trabalho (Idem, p. 21), o que também unifica os dois países. Em vez de propiciar a proteção, a Sécurité Sociale torna-se um fardo, e em vez de direitos, esse discurso preconiza contratos. Como já dissemos, o sucesso dessa pressão tem sido apenas pontual na França, em comparação com 
outros países da Europa (Boschetti, 2012). Mas há uma ampla difusão desses argumentos, especialmente para a periferia do capitalismo, na qual princípios liberais como a neutralidade atuarial vem colocando governos de direita e de centro-esquerda num mesmo diapasão: o do déficit da Previdência.

Considerando esses traços gerais da proteção social e da Seguridade Social francesa, que relações, além das que procuramos apontar até aqui, se pode efetivamente traçar entre estes e a experiência brasileira? No Brasil, temos, desde a Constituição de 1988, estabelecido que a Seguridade Social envolve políticas e direitos relacionados à Previdência Social, à Saúde e à Assistência Social, ${ }^{47}$ políticas públicas que foram posteriormente reguladas por leis orgânicas complementares. A Constituição também firmou o Orçamento da Seguridade Social como parte do orçamento do Estado, e foram criados mecanismos de inspiração beveridgeana para seu financiamento, para além da contribuição de empregados e empregadores, de inspiração bismarckiana. Exemplo disso foi a criação da Contribuição para o Financiamento da Seguridade Social (Cofins) e da Contribuição Social sobre Lucro Líquido (CSLL). Posteriormente, foi criada também a Contribuição Provisória sobre Movimentação Financeira (CPMF) e há outros mecanismos fiscais com incidência mais residual no financiamento da seguridade social brasileira. As políticas e os recursos são geridos pela União, que concentra a maior parte da carga tributária do país: 69,91\% em 2010. A carga tributária nacional total representou, em 2010, $33,56 \%$ do PIB, sendo que $23,46 \%$ concentraram-se na União, o que justifica nosso movimento de considerar para efeitos da análise os recursos federais no Brasil. O governo federal transfere recursos, por obrigação constitucional, para estados e municípios, mas estes últimos também alocam recursos fiscais próprios nas políticas sociais, sobretudo na Saúde, Assistência Social e Educação, mas que não são considerados no âmbito deste estudo. Para viabilizar a gestão das políticas e as transferências para os entes federativos subnacionais foram criados fundos especiais, nos quais são alocados os recursos orçamentários. Foram criados, por fim, instrumentos de controle democrático das políticas de Seguridade Social, os

47. Há um longo e interessante debate sobre a utilização do termo e o próprio estatuto da Assistência Social no Brasil, que difere da reflexão francesa anteriormente citada. Então, desde a Constituição de 1988 e a Lei Orgânica da Assistência Social, de 1993, fala-se sobre a assistência como direito. Evidentemente, esta é uma construção histórica atravessada por muitas tensões. Para este debate, da ampla bibliografia disponível, destacamos: Sposati et al. (1985); Yasbek (1993); Boschetti (2003 e 2006); Mota et al. (2010). Do ponto de vista institucional, há ampla documentação disponível hoje no Ministério do Desenvolvimento Social e Combate à Fome (MDS). 
conselhos e conferências, e periodicamente são revistos os planos nacionais e subnacionais referentes às políticas de Seguridade Social. ${ }^{48}$

O desenho do sistema de Seguridade Social brasileiro não envolve direitos referentes à moradia, os quais são extremamente frágeis no Brasil, como revela a destinação orçamentária (Tabelas 1 e 2) e desconhece as chamadas prestações familiares do sistema francês, como explicitamos anteriormente. Outra questão a ser ressaltada é que o orçamento da Seguridade Social envolve o seguro-desemprego, que é um direito constitucional de seguridade, tem suporte do Fundo de Amparo ao Trabalhador, recolhe recursos do PIS-Pasep, dos quais 60\% são destinados para aquele programa e outros de geração de emprego e formação da força de trabalho, e 40\% são destinados ao BNDES para programas de desenvolvimento (Santos, 2006).

A partir dessas considerações gerais sobre a proteção social e seu financiamento nos dois países, podemos avançar na análise comparada das despesas nesse campo, considerando nas Tabelas 1 e 2 os conceitos semelhantes. Vejamos então a Tabela 3, a seguir, onde desagregamos aqueles dados para dar a eles melhor visibilidade.

A Tabela 3 reúne as despesas nacionais em Previdência, Saúde, Assistência Social e Trabalho nos dois países, na perspectiva de mostrar agregados que representam universos semelhantes de cobertura das políticas sociais. No Brasil, a delimitação deste universo é relativamente mais simples, pois o conjunto dos dados está no orçamento federal. No caso francês, considerando a fragmentação do sistema de proteção social, optamos por analisar o agregado maior de recursos, diga-se, o Regime General da Sécurité Sociale, somado ao aporte do Estado nacional. Essa opção leva a um dado cuja análise precisa ser muito cuidadosa: o de que a França investe mais em Saúde que em Previdência Social. Na verdade, as demais assurances complementaires, incluindo os regimes particulares e especiais, não estão compondo o dado. Com isso, o nosso universo delimitado leva a um gasto maior em Saúde que em Previdência na França, o que não é confirmado pelas análises que consideram o conjunto da proteção social, onde a Previdência é também a maior rubrica de gasto. Podem existir também gastos cruzados de Previdência e Saúde, considerando que são duas políticas profundamente imbricadas no contexto dos regimes e do financiamento cruzado. O Eurostat (acesso em 21 de junho de 2012), cujos dados sobre a proteção social estão atualizados até 2009, indica uma cobertura na França de

48. Sobre a Seguridade Social brasileira há inúmeros trabalhos de referência, mas destacamos aqui: Behring e Boschetti (2006); Boschetti (2003 e 2006); Mota (1995); Salvador (2010); CFESS (2001); Fleury (1994 e 2004); Teixeira (1990) e Vianna (1998 e 1999). 


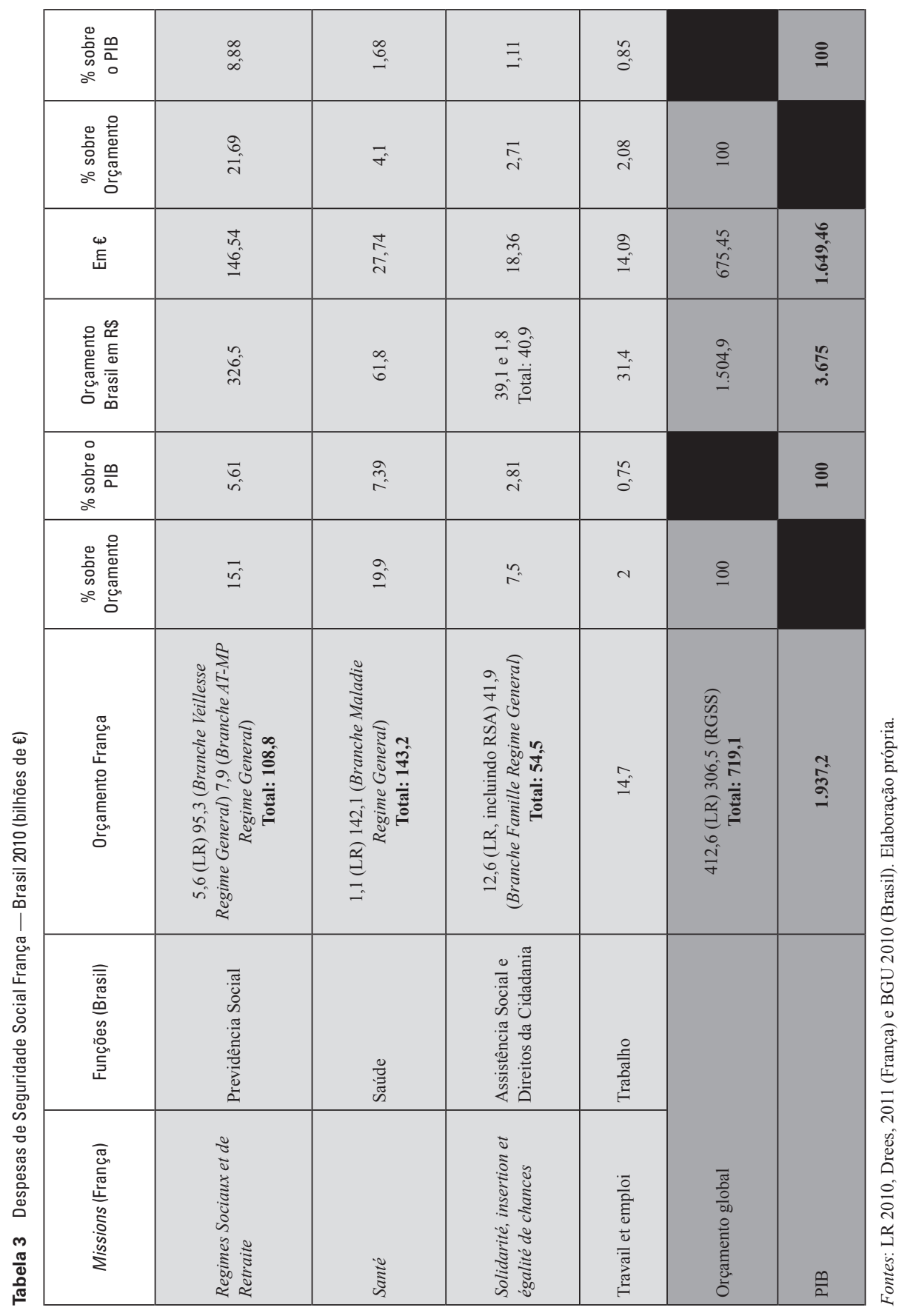


$33,05 \%$ do PIB naquele ano, sendo 14,5\% em aposentadorias e pensões, ou seja, um impacto bem maior do que o identificado a partir da base empírica aqui tratada. No entanto, as contas do Eurostat consideram o conjunto do gasto social, o que inclui o Estado nacional, os entes subnacionais, e o conjunto das assurances. Nosso cuidado, então, deve ser o de não superestimar as despesas de Saúde ou subestimar as despesas de Previdência na França, explicitando que estamos nos aproximando, no âmbito deste estudo, de um universo semelhante entre os dois países em foco, o que nos levou a delimitar a despesa federal e, no caso da França, o Regime General de Sécurité, que reúne a maior parte das despesas, cobrindo $75 \%$ da população aposentada (Barbier e Théret, 2009, p. 50). O eixo do trabalho foi se revelando importante, considerando o peso do seguro-desemprego e das políticas ativas de formação profissional e geração de emprego e renda. No Brasil, esta função é financiada basicamente pelo Orçamento da Seguridade Social, embora tenha uma fonte específica, e na França, pelo Budget de L'État e por cotizações específicas para a Unedic, de forma que incluímos esse eixo na nossa base de dados.

Postas essas questões preliminares, observemos o campo delimitado. $\mathrm{Na}$ França o conjunto desses gastos nacionais representou $16,56 \%$ do PIB, em 2010 , e 44,5\% das contas consideradas (LR 2010 e contas da Sécurité Sociale - Regime General 2010). Para o Brasil, temos que o governo federal aloca $12,52 \%$ como proporção do PIB e 30,58\% do orçamento federal nos quatro eixos. A França investe quase a metade dos recursos aqui computados, lembrando sempre que este volume é ainda maior em gastos sociais tipicamente de Seguridade Social, enquanto o Brasil, com um PIB pouco menor, e com uma margem menos alargada de expansão deste número, se consideramos os mesmos critérios da França, aloca pouco mais que um terço de recursos para uma população três vezes maior, como vimos antes. São números que descortinam a existência de uma proteção social estruturada e fundada no pleno emprego e no reconhecimento de direitos, à francesa, mesmo com os desgastes do período, e a fragilidade da proteção social no rico país pobre, que é o Brasil, submetido historicamente na hierarquia-mundo a constrangimentos econômicos e sociais, com o conluio interno das classes dominantes, e que delineia tardiamente a Seguridade Social fora de um contexto de pleno emprego e sem uma cultura de direitos efetiva, mas com os avanços constitucionais de 1988, a despeito da ofensiva contrarreformista.

Os dados revelam um forte desnível do gasto social brasileiro, considerando o peso da Previdência Social (8,88\% do PIB e 21,69\% do orçamento) e dos demais eixos no orçamento e no PIB (Tabela 3), enquanto a França guarda um equilíbrio 
maior entre Previdência e Saúde, fortemente marcados pela lógica do seguro, e possui uma aide sociale com menos recursos que as demais políticas, mas com crescente importância hoje em virtude do empobrecimento da população, e, claramente, com maior volume de recursos que no Brasil, e que envolve a diversidade de benefícios na forma das prestações sociais familiares, um elemento de forte diferenciação entre um padrão de proteção e de gasto público e outro. O gasto previdenciário brasileiro federal, que tem como principal fonte de recursos a contribuição de empregados e empregadores, é maior que o francês, inclusive pela referência citada acima do Eurostat. No entanto, a cobertura previdenciária brasileira é menor que a francesa, considerando a PEA e os dados de emprego sinalizados anteriormente, e cuja análise detalhada e densa podemos encontrar em Lopes (2011), que mostra que cerca 50 milhões da PEA ficam fora do sistema no Brasil, sem necessariamente cumprir os requisitos de acesso aos programas assistenciais ultrafocalizados (ex. Programa Bolsa Família). Ambos os sistemas previdenciários, por seu turno, são organizados sob a lógica do seguro, contributiva, ainda que contem com aportes fiscais. Como explicar, então, essa diferença? Uma incidência neste dado é a de que o Regime Geral brasileiro tem uma cobertura de cerca de 20 milhões de aposentados, enquanto na França são cerca de 10 milhões, aproximadamente, vinculados ao Regime General, o que tem relação com o tamanho da população economicamente ativa dos dois países e muito claramente com o grau de assalariamento da população, muito maior na França que no Brasil, mesmo no contexto da crise. Por outro lado, como hipótese, podem incidir também questões relacionadas à estrutura de renda e de contribuição que não teremos condições de explorar aqui.

Em contrapartida, considerando a população, os indicadores sociais historicamente mais frágeis, e a dimensão continental do território, é evidente o subinvestimento brasileiro em saúde, quase cinco vezes menor que na França, considerando o orçamento, e quatro vezes menor, com base no PIB. Cabe refletir que a saúde no Brasil não é pautada pela lógica do seguro como na França, o que requisitaria um aporte de recursos muito maior para que o direito à saúde fosse efetivamente universalizado, embora o seja no marco legal. A existência de uma potente rede privada - por exemplo, 69\% dos hospitais brasileiros são privados, e oferecem apenas $38 \%$ de vagas ao Sistema Único de Saúde (SUS), com base em convênios, segundo Almeida, $2011^{49}$ — e de planos de saúde para os que podem pagar, mostra o

49. Informe ENSP, de 30/6/2011. Disponível em: <http://www.ensp.fiocruz.br/portal-ensp/informe/site/ materia/detalhe/26264>. Acesso em: 21 jun. 2012. 
quanto o subfinanciamento dessa política dá base material à mercantilização, já que a precariedade em parcela significativa do sistema público, as filas, a falta crônica de material, dentre outros, minam a confiança no SUS. Ainda assim, o SUS atende a cerca de $75 \%$ da população brasileira sem condições de acesso aos planos privados. A Saúde na França articula-se a uma lógica contributiva, sendo, portanto, muito sensível à dinâmica do trabalho. Nesse sentido, a Saúde é a política que mais requisita a expansão de mecanismos fiscais de financiamento, bem como recebe pressões para a universalização da oferta, sobretudo das baixas rendas, que resultaram na criação da Coverture Maladie Universelle (CMU), assegurando acesso à saúde aos que não podem de fato pagar uma assurance maladie, e da Coverture Maladie Universelle Complementaire (CMU-C) aos que tem menores condições de contratar a assurance, assegurando reembolsos de cuidados médicos. Por outro lado, há hoje pressões privatistas importantes na França, seja por parte do setor médico liberal, seja pelo crescimento exponencial das muttueles santé, especialmente no contexto do neoliberalismo. Se no campo previdenciário os fundos de pensão e a repartição não prosperaram, na Saúde houve um campo de expansão maior da mercantilização. Barbier e Théret (2009, p. 66) caracterizam que a Saúde oscila entre a privatização limitada e a cobertura universal, sendo que o Regime General assume cerca de $82 \%$ das suas despesas.

$\mathrm{Na}$ Assistência Social encontramos uma despesa quase três vezes menor no Brasil, em comparação com a França, considerando o orçamento e o PIB. Se no Brasil temos o desenvolvimento do Sistema Único de Assistência Social (Suas), vale lembrar que mais de $90 \%$ do orçamento da Assistência Social destina-se à transferência de renda. Contudo, estamos longe de constituir o suporte em mínimos sociais (em número de nove, segundo Barbier e Théret, 2009, p. 88) e de alocações familiares (CNAF, Sécurité Sociale) disponíveis na França. Além disso, se na França avançaram os programas que exigem comprovação de renda, os critérios estão distantes de serem tão draconianos quanto os brasileiros, como vimos acima ao comentar as medidas da pobreza no Brasil.

Quanto ao eixo trabalho, os dois países investem um volume semelhante de recursos, mas este é também um dado que precisa ser mediado pelos elementos que levantamos no item 1 deste texto, que delineiam as características do mundo do trabalho nos dois países, ou seja, existem necessidades muito diferentes num país que viveu o pleno emprego keynesiano e que apesar da crise mantém fortes características da chamada relação salarial, e outro que não conheceu essa experiência na sua história e cuja força de trabalho se encontra em cerca de 50\% na informalidade, 
sem direitos e sem contribuição para a proteção social, o que demanda um forte investimento nesse conjunto de políticas sociais de Seguridade Social e em outras políticas públicas, mas encontra fortes obstáculos numa economia política periférica de expandi-lo.

\section{Breve conclusão}

Este artigo é o resultado de uma aproximação que está longe de ser esgotada. No entanto, a incursão realizada permite finalizar chamando a atenção para a perversidade dos mecanismos de ajuste fiscal brasileiros, que de fato constrangem as possibilidades de expansão da proteção social, considerando o peso da dívida pública, o superávit primário e os mecanismos que retiram recursos da Seguridade Social..$^{50}$ Por outro lado, a austeridade fiscal ronda a Europa já há algum tempo, cortando postos de trabalho e realizando contrarreformas importantes, mesmo que resistências políticas e filtros histórico-estruturais se interponham como no caso francês. Portanto, essa dinâmica contemporânea do capitalismo comandada pela hegemonia da finança, entrelaça os dois países. Entretanto, há que observar o que difere estruturalmente.

E um elemento central de diferença é o espantoso dado do peso da dívida no orçamento público brasileiro - com a produção do superávit primário e todos os mecanismos daí decorrentes —, apesar de uma relação dívida/PIB menor que a francesa, mesmo antes de 2007. Este elemento requisita alguns comentários finais. Dourille-Feer et al. (2011) nos ajudam a pensar sobre a questão. Partem da constatação de que há um momento favorável aos países em desenvolvimento quanto ao refinanciamento das dívidas externas, em função das baixas taxas de juros praticadas ao norte, o que torna a dívida desses países aparentemente sustentável e promove certa euforia nos gestores. O exemplo brasileiro é citado aqui explicitamente (Idem, p. 29). Na verdade, essa sustentabilidade tem um custo, e essa é uma escolha política: comprimir as despesas sociais para destinar recursos aos credores. Os demais elementos que dão a aparência da sustentabilidade são o preço das

50. Que vão além da DRU. Na verdade, há inúmeros mecanismos de renúncia fiscal que incidem sobre fontes de financiamento da Seguridade Social brasileira e que foram ampliados no contexto do Plano de Aceleração do Crescimento (PAC), como tivemos a oportunidade de demonstrar em Behring et al., 2007. 
matérias-primas e o fluxo de capitais (assegurado pelas altas taxas de juros praticadas). São três dimensões extremamente conjunturais e que, a rigor, não poderiam estar relacionadas ao termo sustentabilidade. Quando se pensa para além da dívida externa sobre a dívida total, considerando o crescimento exponencial da dívida interna, a conjuntura favorável se torna bastante frágil. Um fato que torna esse contexto mais complexo para os países em desenvolvimento é a formação de bolhas especulativas na China, que importa boa parte das matérias-primas desses países, incluindo o Brasil. Para os autores, a conjuntura frágil, mas ainda favorável, deveria incentivar atitudes soberanas dos Estados no sentido de auditar e contestar total ou parcialmente a dívida. Até porque se os credores ao norte, detentores de títulos da dívida pública desses países, foram capazes de lidar com as enormes perdas recentes no contexto da especulação. Não seriam perdas muito menores globalmente que iriam desestabilizar e deixar nervosos os mercados, que o diga o Clube de Paris em sua estacionada relação com a Argentina após 2001 (Idem, p. 39). No entanto, é essa sangria segura e cotidiana o verdadeiro alimento dos credores: a punção de mais-valia socialmente produzida, sustentada pela submissão, pela chantagem especulativa, pelas relações desiguais e combinadas na hierarquia mundo, com a aquiescência interna das classes dominantes. Trata-se também, evidentemente, de assegurar a possibilidade de aquisição de patrimônio, de ativos, haja vista o gigantesco movimento patrimonial engendrado com as privatizações (Behring, 2003). Assim, existem condições político-econômicas diferenciadas entre o Brasil e a França, embora ambos os países estejam vivendo à sua maneira a punção do capital financeiro. E as escolhas feitas no terreno da política e das pressões da luta social são decisivas nesse terreno.

Observamos também, como campo comum mediado pelas diferenças, o ambiente de pressões pela mercantilização das políticas sociais em variadas formas. Há ainda o crescimento de políticas sociais que exigem comprovação de renda, bem como que passam estímulo ao consumo, típicas do campo da assistência social. De outro ângulo, há elementos a ser mais bem explorados e que instigam a continuidade das pesquisas, a exemplo de um mergulho detalhado na estrutura fiscal que nos permita discutir os problemas da redistributividade ou não. Chesnais (2011, p. 15) aponta um enfraquecimento dos impostos diretos (renda e lucros das empresas) e fortalecimento dos indiretos, a exemplo da TVA. Dourille-Feer et al. (2011) dizem dos presentes para os ricos a partir da renúncia fiscal, os chamados niches fiscales na França, o que também é sublinhado por Franchet (2011) e reconhecido pela própria Cour des Comptes (2011). Acompanhamos na França, em 2011 e 2012, o 
debate sobre o aumento da TVA, um imposto nitidamente regressivo, inclusive com o discurso de uma TVA social para enfrentar o déficit da Sécurité Sociale, elemento que polarizou as eleições presidenciais francesas. Para Chesnais, o endividamento do Estado francês tem um de seus fundamentos na evasão fiscal e na fraqueza da capacidade extrativa direta do Estado (renda e empresas), que vem lançando a França na estratégia dos empréstimos para financiar seus compromissos.

Ao longo do período de pós-doutoramento, estivemos nas ruas em várias manifestações dos trabalhadores e movimentos sociais na França, nos quais a Sécurité Sociale aparece explicitamente como pauta, onde se denunciou a mercantilização da saúde e exigiu-se mais e melhores alocações, especialmente para a moradia. Finalizamos essa síntese final reafirmando que por trás dos números do orçamento está a política (grande e pequena, nos termos gramscianos). Por trás da maior ou menor autonomia frente aos ditames do lucro está a luta de classes e seus segmentos. As condições de o Brasil enfrentar seus dilemas estruturais estão diretamente relacionadas às pressões dos trabalhadores por medidas de expansão dos direitos e dos gastos sociais, sem o que eles permanecerão parcos, administrando ou gerindo a pobreza, contentando-se com resultados pífios e de largo prazo quanto à desigualdade profunda que marca este país. Parece-nos que as condições na França têm sido maiores e melhores para defender suas conquistas, mesmo com anos de um governo de direita, apesar do ambiente neoliberal das últimas décadas e da crise. Os direitos estão enraizados na cultura política e no cotidiano francês como exigíveis do Estado. Isso faz e fará toda a diferença, especialmente se a classe trabalhadora francesa encontrar formas de unificar as lutas ainda mais fortes que as disponíveis hoje e para além dos organismos tradicionais e institucionais da luta política francesa.

Recebido em 28/6/2012 - Aprovado em 10/12/2012

\section{Referências bibliográficas}

ANFIP. Análise da Seguridade Social em 2010. Brasília: Anfip, jun. 2011. . Análise da Seguridade Social em 2011. Brasília: Anfip, jun. 2012.

ANTUNES, Ricardo. Os sentidos do trabalho: ensaio sobre a afirmação e a negação do trabalho. 2. ed. São Paulo: Boitempo Editorial, 2009. v. 1, 287 p. 
AUBIN, Emmanuel. L'essentiel du droit des politiques sociales 2011-2012. 6. ed. Paris: Gualino Lextenso Éditions, 2011.

AUDITORIA CIDADÃ DA DÍVIDA. Informativo. Brasília, set. 2011.

BASLÉ, Maurice. Le budget de l'État. Paris: La Decouverte, 2004.

BARBIER, Jean Claude; THÉRET, Bruno. Le Système Français de Protection Sociale. Paris: La Découverte, nouvelle édition, 2009.

BEHRING, Elaine Rossetti. Rotação do capital e crise: fundamentos para compreender o fundo público e a política social. In: SALVADOR, Evilasio et al. (Orgs.). Financeirização, fundo público e política social. São Paulo: Cortez, $2012 a$.

. Outubro. 1961. O silêncio sobre a repressão à resistência argelina em Paris. Disponível em: < http://midiaequestaosocial.blogspot.com.br/2012/04/editoria-volta-do-mundo-mundo-da-volta.html >.

. Crise do capital, fundo público e valor. In: BOSCHETTI, Ivanete et al. (Orgs.). Capitalismo em crise, politica social e direitos. São Paulo: Cortez, 2010.

. Acumulação capitalista, fundo público e política social. In: BOSCHETTI, Ivanete et al. (Orgs.). Política social no capitalismo: tendências contemporâneas. São Paulo: Cortez, $2008 a$.

. A lógica do financiamento da Seguridade Social entre 1997 e 2007. In: CONFERÊNCIA MUNDIAL DE SERVIÇO SOCIAL, 19., Salvador. Brasília: FITS/CFESS, $2008 b$.

. Política social no capitalismo tardio. São Paulo: Cortez, 1998.

. Brasil em contrarreforma: desestruturação do Estado e perda de direitos. São Paulo: Cortez, 2003.

et al. Lula no país das maravilhas: uma crítica do PAC. In: CONGRESSO BRASILEIRO DE ASSISTENTES SOCIAIS, 12., Foz do Iguaçu. CD-Room $12^{\circ} \mathrm{CBAS}$. Foz do Iguaçu: CFESS/Abepss/Enesso, 2007.

; BOSCHETTI, Ivanete. Política social: fundamentos e história. São Paulo: Cortez, 2006.

BENSAID, Daniel. Préface de Daniel Bensaid. In: MARX, Karl. Les crises du capitalism: texte inédit. Paris: Éditions Demopolis, 2009.

BEVERIDGE, Sir W. O Plano Beveridge: relatório sobre o Seguro Social e serviços afins. Rio de Janeiro: José Olympio, 1943. 
BOSCHETTI, Ivanete. A insidiosa corrosão dos sistemas de proteção social europeus. Serviço Social \& Sociedade, São Paulo, n. 112, out./dez. 2012.

Assistência Social no Brasil: um direito entre originalidade e conservadorismo. 2. ed. rev. ampl. Brasília: Gesst/SER/UnB, 2003.

Seguridade Social e trabalho: paradoxos na construção das políticas de Previdência e Assistência Social. Brasília: Letras Livres/Editora da UnB, 2006.

Crise do capital e política social. In: BOSCHETTI, Ivanete et al. (Orgs.). Capitalismo em crise, política social e direitos. São Paulo: Cortez, 2010.

; SALVADOR, E. da S. Orçamento da Seguridade Social e política econômica: perversa alquimia. Serviço Social \& Sociedade, São Paulo, v. 87, p. 25-57, 2006.

CCIP. Brésil: un géant accessible. Paris: La Documentation Française, juin 2010.

CFESS (Org.). Carta de Maceió, 2001. Disponível em: <www.cfess.org.br>. Acesso em: 29 jun. 2012.

CHAUI, M. Brasil: mito fundador e sociedade autoritária. São Paulo: Fundação Perseu Abramo, 2000.

CHESNAIS, François. A mundialização do capital. São Paulo: Xamã, 1996.

Les dettes illégitimes. Paris: Raisons D’Agir, 2011.

CONTROLADORIA GERAL DA UNIÃO. Balanço Geral da União, 2010. Brasília: CGU, 2011.

CORNILLEAU, Gérard; MATHIEU et al. Les reformes des retraites dans la crise. Document de Travail de l'OFCE. Paris: Sciences Po, 2010.

COUR DES COMPTES. Résultats et Gestion Budgétaire de L'État: Exercice 2010. Paris: La Documentation Française, mai 2011.

DIDIER, Raphael. Comprendre la dette. Paris: Ellipses, 2011.

DOURILLE-FEER, Évelyne et al. La piège de la dette publique: comment s'en sortir. Paris: Les Liens qui Libèrent et Attac, 2011.

DUVAL, Julien. Le mythe du “trou de la Sécu”. Paris: Éditions Raisons d'Agir, 2008.

DREES. Les Chiffres Clés de la Sécurité Sociale 2010. Republique Française, 2011.

ELBAUM, Mireille. Économie politique de la protection sociale. 2. ed. Paris: Quadrige-PUF, 2011.

ESPING-ANDERSEN, G. As três economias políticas do Welfare State. Lua Nova, São Paulo, n. 24, set. 1991. 
FATORELLI, Maria Lúcia; ÁVILA, Rodrigo. Os números da dívida. Brasília: Auditoria Cidadã da Dívida, 2012.

FERNANDES, Florestan. A revolução burguesa no Brasil: ensaio de interpretação sociológica. 3. ed. Rio de Janeiro: Guanabara, 1987.

FILGUEIRAS, Luiz; GONÇALVES, Reinaldo. A economia política do governo Lula. São Paulo: Contraponto, 2007.

FLEURY, S. Estado sem cidadãos: Seguridade Social na América Latina. Rio de Janeiro: Fiocruz, 1994.

A Seguridade Social inconclusa. In: FLEURY, S. A era FHC e o governo Lula: transição? Brasília: Inesc, 2004.

FMI. Perspectives de L'Économie Mondiale: Reprise, Risques et Rééquilibrage. FMI: Études Économiques et Financières, 2010.

FONTES, Virgínia. O Brasil e o capital imperialismo. Rio de Janeiro: Editora UFRJ, 2010.

FRANCHET, Pascal. Dette publique de la France: des vérités qui dérangent. In: TOUSSAINT, Éric; MILLET, Damien. La dette ou la vie. Bruxelles: Éditions Aden et CADTM, 2011.

HARTMANN, Michael. Internationalisation et spécificités nationales des élites économiques. In: Actes de la Recherche en Sciences Sociales, Paris: CNRS, n. 190, déc. 2011.

HARVEY, D. Condição pós-moderna: uma pesquisa sobre as origens da mudança cultural. São Paulo: Loyola, 1993.

. O novo imperialismo. São Paulo: Loyola, 2004.

. O neoliberalismo: história e implicações. São Paulo: Loyola, 2008.

HUSSON, Michel. El capitalismo tóxico. Viento Sur, Madrid, n. 101, nov. 2008.

LIPIETZ, Alain. Miragens e milagres: problemas da industrialização no Terceiro Mundo. São Paulo: Nobel, 1988.

LOPES DA SILVA, Maria Lucia. Previdência Social no Brasil: (des)estruturação do trabalho e condições para sua universalização. São Paulo: Cortez, 2012.

LORDON, Frédéric. Jusqu'à quand? Pour em finir les crises financières. Paris: Raisons D’Agir, 2008.

LÖWY, Michael. Ecosocialisme: l'alternative radicale a la catastrophe écologique. Paris: Mille et Une Nuits, 2011.

MANDEL, E. O capitalismo tardio. São Paulo: Nova Cultural, 1982. 
MÉSZÁROS, I. Para além do capital: rumo a uma teoria da transição. Trad. de Paulo César Castanheira e Sérgio Lessa. São Paulo: Boitempo, 2002.

MINISTÉRIO DA FAZENDA. Carga tributária do Brasil 2010. Análise por tributos e bases de incidência. Brasília, set. 2011.

MINISTÉRIO DO PLANEJAMENTO, ORÇAMENTO E GESTÃO. Manual Técnico do Orçamento 2010 (MTO) (versão 6). Brasília: MPOG, 2010.

MOTA, A. E. Cultura da crise e Seguridade Social: um estudo sobre as tendências da Previdência e da Assistência Social brasileira nos anos 80 e 90. São Paulo: Cortez, 1995. (Org.). O mito da Assistência Social. São Paulo: Cortez, 2010.

MOORE JR., Barrington. As origens sociais da ditadura e da democracia. Rio de Janeiro: Martins Fontes, 1983.

OCDE. Statistiques de base de la zone euro, 2010. OCDE: Ed. de l'OCDE, Études Économiques de l'OCDE, 2010.

OLIVEIRA, F. de. Os direitos do antivalor: a economia política da hegemonia imperfeita. Petrópolis: Vozes, 1998.

PALIER, Bruno. Gouverner la Sécurité Sociale. Paris: PUF, 2005.

POCHMANN, Márcio. Nova classe média? O trabalho na base da pirâmide social brasileira. São Paulo: Boitempo, 2012.

POLANYI, K. A grande transformação: as origens de nossa época. 2. ed. Rio de Janeiro: Campus, 2000.

PRADO JR. Formação do Brasil contemporâneo: colônia. São Paulo: Companhia das Letras, 2011.

RÉPUBLIQUE FRANÇAISE. Le Comptes de L'État 2010. Paris. Disponível em: <www. performance-publique.gouv.fr>. Acesso em: 16 jun. 2012.

Compte Général de L'État 2010. Annexe au Project de Loi de Réglement. Paris. Disponível em: <www.performance-publique.gouv.fr>. Acesso em: 16 jun. 2012.

Donnés Budgétaires 2010. Paris. Disponível em: <www.performance-publique. gouv.fr>. Acesso em: 16 jun. 2012.

ROL, Sandrine. Un grand marché de consommateurs en revenir. In: CCIP. Brésil: un géant accessible. Paris: La Documentation Française, juin 2010.

ROSANVALLON, P. La crise de l'État-providence. Paris: Éditions du Seuil, 1981.

SABOIA, J. Regulação, crises e relação salarial fordista. Texto para discussão, IEI/UFRJ, n. $177,1988$. 
SALVADOR, Evilásio. Fundo público e Seguridade Social. São Paulo: Cortez, 2010.

SANTOS, Vivian Machado dos. Por dentro do FAT. Revista do BNDES, Rio de Janeiro, v. 13, n. 26, dez. 2006.

SCHREYER, Paul; KOECHLIN, Francette. Parités de pouvoird'achat: mesure et utilisations. OCDE. Cahiers Statistiques, n. 3, mar. 2002.

SPOSATI, A. et al. Assistência na trajetória das políticas sociais brasileiras. São Paulo: Cortez, 1985.

TEIXEIRA, A. Do seguro à seguridade: a metamorfose inconclusa do sistema previdenciário brasileiro. Rio de Janeiro: UFRJ/IEI, 1990.

TITMUSS, Richard M. Social Policy: an Introduction. London: Pantheon Books, 1974.

UNEDIC. Rapport Financier 2010. Paris: Unedic, 2011.

VIANNA, M. L. T. W. A americanização (perversa) da Seguridade Social no Brasil: estratégias de bem-estar e políticas públicas. Rio de Janeiro: Revan/Iuperj/Ucam, 1998.

. Seguridade social: três mitos e uma mentira. Universidade e Sociedade, Brasília, n. 19, ago. 1999.

VV.AA. Manifeste d'Économistes Atterés. Paris: Les Liens qui Libèrent, 2010.

YAZBEK, M. C. Classes subalternas e Assistência Social. São Paulo: Cortez, 1993. 